\title{
Políticas Migratórias no Brasil e a Instituição dos "Indesejados": A Construção Histórica de uM ESTADO DE EXCEÇÃo PARA ESTRANGEIROS
}

\author{
Cynthia Soares Carneiro*
}

\begin{abstract}
1 Introdução. 2 Ameaça à segurança nacional e ao estado de exceção nas democracias contemporâneas. 3 A instituição legal dos indesejáveis e de sua deportabilidade. 4 Primódios de uma tradição brasileira: tráfico, segregação e repressão. 5 A declaração dos "indesejáveis" na Primeira República. 6 As políticas eugenistas dos governos de Getúlio Vargas. 7 O Estatuto do Estrangeiro, o estado de exceção e a nova Lei de Migração. 8 Conclusão. Referências.
\end{abstract}

\section{RESUMO}

A participação dos imigrantes na I Conferência sobre Migração e Refúgio resultou em um levantamento circunstanciado da situação de restrições a direitos a que estão sujeitos no Brasil. Evidenciou-se, igualmente, que tais restrições são consequência de normas e práticas institucionais arraigadas junto aos órgãos brasileiros responsáveis pelo controle migratório. As recomendações apresentadas pelos imigrantes no âmbito da conferência contribuíram para a edição da Lei 13.445/2017, denominada Lei de Migração. A partir do trabalho etnográfico realizado junto a COMIGRAR, este artigo se dedica a um estudo exploratório relativo aos decretos migratórios editados desde o período monárquico, percorrendo o período getulista e suas políticas higienistas e eugenéticas, até o recém-revogado Estatuto do Estrangeiro. A abordagem tem como objetivo evidenciar uma tradição discriminatória que tem levado à precarização do trabalho do estrangeiro no Brasil. De acordo com os conceitos formulados por Giorgio Agamben acerca do homo sacer e do estado de exceção na modernidade, procura-se demonstrar que tal percurso histórico cristaliza práticas oficiais restritivas a direitos, o que pode comprometer o paradigma humanista da nova Lei de Migração.

Palavras-chave: Discriminação. Estado de exceção. Homo sacer. Imigração. Lei de Migração.

\section{INTRODUÇÃO}

Os esforços realizados nos últimos anos no sentido de revogar o Estatuto do Estrangeiro vigente, Lei 6.815/80 (BRASIL, 1980), iniciaram-se ainda em 2005. Naquela ocasião,

* Professora de Direito Internacional no curso de Graduação e Pós-Graduação stricto sensu da Faculdade de Direito de Ribeirão Preto/ USP, onde também coordena projetos de pesquisa e extensão universitária sobre migração internacional e direito dos imigrantes no Brasil. E-mail: <cynthia.carneiro@usp.br>. 
resultaram no Projeto de Lei 5.655/2009 (BRASIL, 2009b), porém as críticas à insuficiência desse estatuto no reconhecimento do imigrante como destinatários de direitos fez intensificar, a partir de 2012, o debate acerca da necessidade de uma Lei de Migrações fundada em princípios de direitos humanos internacionais e dos direitos e garantias instituídos pela Constituição de 1988 (BRASIL, 1988).

A nova lei de migrações deveria finalmente superar o paradigma da segurança nacional, fundado em um estado de exceção relativo aos imigrantes justificado na ameaça às instituições do Estado e aos direitos dos nacionais. ${ }^{1}$

Esses esforços culminaram na realização da COMIGRAR, de outubro de 2013 a junho de 2014. Nesse período, foram realizadas, em diversas cidades do Brasil, as conferências parciais que compuseram a I Conferência sobre Migração e Refúgio, promovida por iniciativa do Ministério da Justiça com suporte do Ministério do Trabalho e Emprego e do Ministério das Relações Exteriores, além da assessoria direta da Organização Internacional para Migrações (OIM). ${ }^{2}$

O resultado foi a elaboração de mais de 2.500 recomendações consolidadas no Caderno de Propostas (BRASIL, 2014b), que traduzem e detalham as dificuldades vividas pelos imigrantes no Brasil e as restrições impostas ao acesso a direitos básicos, de natureza individual, como o de portar documento de identificação, de ser consultado em questões de seu interesse, e social, como acesso desembaraçado à educação, à saúde pública fundamental, à segurança e ao trabalho digno (BRASIL, 2014a).

Esse quadro restritivo e discriminatório, porém, é anterior ao recém-revogado Estatuto do Estrangeiro. A análise das políticas migratórias brasileiras no tempo permite aferir que um regime de exceção a direitos tem submetido, desde sempre, os trabalhadores imigrantes no país. Atualmente, esta discriminação ocorre, inclusive, em relação a trabalhadores beneficiários pelo Acordo de Residência do Mercosul, ${ }^{3}$ apesar de o tratado promover, justamente, a residência regular e o trabalho formal e digno para os originários de seus Estados-Partes, além da extinção do tráfico para exploração de pessoas, uma realidade entre suas fronteiras.

Diante dessa tradição jurídica, do contexto internacional de restrição em relação a imigrantes e refugiados e do próprio contexto interno de limitação de direitos, inclusive para nacionais, o que veio traduzido nos 27 vetos a direitos impostos ao texto original, tudo está a indicar que a nova Lei de Migração, Lei 13.445/2007 teve sua finalidade e princípios comprometidos desde o procedimento de sanção pelo Executivo (BRASIL, 2017).

Fruto do esforço conjunto de associações de representação e apoio a imigrantes, que atuaram com o Congresso Nacional - destacando-se, dentre essas, a Missão Paz, sediada em São Paulo, que integra a Congregação Scalibriana, a Cáritas Arquidiocesana da cidade de São Paulo, além de organizações não governamentais, como a Conectas Direitos Humanos e o Instituto Terra, Trabalho e Cidadania (ITTC) -, esse empenho foi essencial para a aprovação de uma lei baseada em direitos humanos e na dignidade da pessoa do imigrante e em sua família. ${ }^{4}$ 
Essa mobilização foi promovida por órgãos públicos federais, destacando-se a Secretaria Nacional de Justiça e o Departamento de Estrangeiros, órgãos do Ministério da Justiça que têm promovido, na última década, audiências públicas com imigrantes, combinadas com consultas a especialistas, para uma nova legislação migratória legitimada nos direitos humanos. Como um dos resultados positivos desse processo de mobilização e debate, tem-se a criação do Centro de Referência e Acolhimento de Imigrantes da cidade de São Paulo, instituído em novembro 2014, o que evidencia a importância de integração entre políticas públicas federais e municipais para a materialização de direitos civis e sociais à população brasileira.

Este artigo é produto secundário do trabalho de acompanhamento das conferências parciais da COMIGRAR realizadas na cidade de São Paulo. Não descreve e analisa as restrições experimentadas pelos imigrantes e refugiados, o que já foi feito parcialmente em outros trabalhos (CARNEIRO, 2015a, 2016b), mas destaca, por meio dos decretos migratórios editados no Brasil desde o século XIX, a situação de discriminação legal relativa aos imigrantes no país. Portanto, é um trabalho exploratório em uma perspectiva de longa duração e sistêmica, como propõe Immanuel Wallerstein (WALLERSTEIN, 2011).

$\mathrm{Na}$ primeira parte, apresentam-se o conceito e as categorias do estado de exceção nas democracias constitucionais contemporâneas, com especial referência a Giorgio Agamben nos seus estudos sobre o homo sacer (AGAMBEN, 1996, 2007, 2010).

Em seguida, reporta-se às normas relativas aos estrangeiros no Brasil, desde os primeiros decretos portugueses, que, embora de forma incipiente, já expressavam a desigualdade jurídica entre os brasileiros, ou residentes, e os estrangeiros, passando pelas primeiras décadas do século XX, quando a discriminação adquiriu conteúdo legal, com destaque para o Estado Novo (1936-1945).

Finalmente, no apogeu da Guerra Fria e em período marcado pelo centralismo autocrático dos governos militares, esse percurso legal foi consolidado no Estatuto do Estrangeiro, que instituiu a estrutura de controle migratório no Brasil ainda vigente e em nada alterada pela Lei de Migração.

Da mesma forma que as normas que o precederam, o Estatuto do Estrangeiro tem seu fundamento jurídico na necessidade de o Estado garantir a segurança nacional ameaçada pelos estrangeiros indesejáveis, o que o leva a constituir juridicamente esses estrangeiros como ameaça permanente às instituições estatais e a seus nacionais, justificando sua discriminação e seu reconhecimento como semi-sujeitos de direitos.

Em suas considerações finais, apresenta o contexto que marca a promulgação da Lei de Migrações que, a considerar os vetos interpostos ao texto original e o número significativo de normas de eficácia contida, a depender de regulação administrativa, aponta, seguramente, para a manutenção dos fundamentos jurídicos e para as práticas institucionais discriminatórias, que tem sido historicamente registrada por decretos, leis ou resoluções normativas relativas aos migrantes no Brasil. 


\section{AMEAÇA À SEGURANÇA NACIONALE AO ESTADO DE EXCEÇÃONAS DEMOCRACIAS CONTEMPORÂNEAS}

A Lei 6.815/80 (BRASIL, 1980), conhecida como Estatuto do Estrangeiro, foi objeto de críticas desde a promulgação da Constituição de 1988 (BRASIL, 1988), por expressar flagrantes restrições a direitos desde então vigentes no Brasil, circunscrevendo os trabalhadores imigrantes em uma zona de exceção a direitos somente garantidos aos nacionais. Essa discriminação tem como efeito a formação de uma população sujeita a formas aviltantes de trabalho, que submete os imigrantes à subordinação econômica, ao preconceito social e, inclusive, à criminalização, podendo ser penalizados por atos que aos nacionais são considerados direitos, como bem exemplifica o recente caso da Professora Maria do Rosário Barbato, professora da Faculdade de Direito da UFMG, intimada por meio do Reitor da instituição para responder a inquérito aberto por duas delegadas da Polícia Federal em Minas Gerais por exercício de atividade sindical. ${ }^{5}$

Apesar de não possuir o perfil de um trabalhador imigrante em estado de vulnerabilidade, o ocorrido com a professora de Direito Coletivo do Trabalho retrata o estado de exceção dirigido aos imigrantes e refugiados, não apenas no Brasil, mas também àqueles que se dirigem às economias centrais do sistema-mundo moderno. ${ }^{6}$

Episódios que evidenciam a propriedade da tese de Giorgio Agamben acerca do biopoder exercido pelo Estado Nacional moderno sobre a população em seu território, o que ocorre desde as primeiras declarações de direito editadas a partir do século XVIII, ao mesmo tempo em que passa a articular e a restringir "gradualmente os círculos do ius soli e do ius sanguinis" na definição de quem é nacional e não nacional (AGAMBEN, 2010, p. 126), um poder soberano que, nas primeiras décadas do século XX, desnaturaliza e desnacionaliza em massa seus cidadãos de acordo com a conveniência dos interesses nacionais (AGAMBEN, 2010, p. 128).

Nas últimas décadas, conforme destaca o próprio autor, tal política volta-se, hegemonicamente, contra imigrantes. Enfim, contra os não nacionais, revestidos, na contemporaneidade, dos atributos de descartabilidade e "matabilidade", como um homo sacer moderno (AGAMBEN, 2010, p. 113). ${ }^{7}$

Um estado de exceção que, diferentemente do conceito clássico, não se configura como anomia ou ausência completa do Direito, mas, ao contrário, caracteriza-se justamente pela edição de normas jurídicas discriminatórias, prática que, em relação aos estrangeiros, recrudesce após os ataques ao World Trade Center e ao Pentágono, em 2001 (AGAMBEN, 2007, p. 14) e que aprofunda com os decretos migratórios emitidos por Donald Trump logo após sua posse como presidente dos EUA. ${ }^{8}$

Tanto no Direito Romano como no Direito medieval de Graciano e Tomás de Aquino, o estado de exceção já estava associado ao estado de necessidade, mas caracterizado pela completa anomia, ou seja, pela suspensão de todo direito e de qualquer sistema que não fosse o de exceção. Sua natureza era, portanto, exclusivamente política e extrajurídica. 
Na França revolucionária, o estado de exceção foi frequentemente declarado em situações de grave convulsão social. Desde então, o estado de exceção passa a configurar um direito subjetivo "natural ou constitucional" do Estado nos momentos de emergência política e militar, ou nas graves crises econômicas, situações recorrentes durante todo o século XIX até meados do século XX.

Desse modo, Agamben (2010, p. 22) entende o estado de exceção como a categoria jurídica que melhor define e expressa a soberania do Estado Nacional moderno. Segundo o autor, até os Estados constitucionais e democráticos contemporâneos têm seus campos ou "espaços permanentes de exceção" (AGAMBEN, 2010, p. 171), em vista de determinadas circunstâncias ou em relação a grupos de pessoas. ${ }^{9}$ Portanto, o estado de exceção torna-se regra, e não um evento provocado por uma situação excepcional e temporária. Contemporaneamente, Agamben identifica os fundamentos teóricos desse estado de exceção constitucionalizado em Carl Schimitt, ${ }^{10}$ e Santi Romano (AGAMBEN, 2007, p. 18-43) e exemplifica sua materialização jurídica nas leis que passam a ser editadas por Estados europeus a partir dele para promover a desnacionalização em massa de determinados cidadãos (AGAMBEN, 2010, p. 128). ${ }^{11}$

Como expressão da soberania estatal, o estado de exceção estabelecido juridicamente na modernidade é realizado por meio de normas que se concentram no Chefe de Estado e no aparato executivo dele derivado, todos os atributos estatais, especialmente o de decidir sobre a vida de um indivíduo. No caso do imigrante, o poder exercido pelo Estado faz que este tenha uma vida economicamente explorável e um corpo politicamente deportável, o que o institui, juridicamente, como uma existência que não merece realizar-se plenamente (AGAMBEN, 2007, p. 11-20; AGAMBEN, 2010, p. 132-138).

Neste início do século XXI, a sucessão de conflitos armados, desastres ambientais e crises econômicas recrudescem o empobrecimento da população nas áreas periféricas do capitalismo global, localizadas na América Central e na do Sul, na África, no Oriente Médio e no Leste Asiático. Essa série de fatores conjugados tem estimulado grandes fluxos migratórios, fenômeno que mobiliza Estados e Organismos Internacionais para o debate e a busca de solução para os grandes deslocados territoriais. Discute-se, inclusive, se, diante desse contexto irreversível, é plausível que Estados contemporâneos continuem aplicando políticas restritivas e justifiquem, sob o argumento do estado de necessidade e da segurança nacional, a exceção de direitos como paradigma dominante de governo em relação à população imigrante, especialmente, àquela em situação de maior vulnerabilidade (UNITED NATIONS, 2016).

Sobre o tema também foram os debates que precedem a aprovação da Lei de Migração (Lei 13.445/2017) (BRASIL, 2017), que deveria representar significativa ruptura em relação às normas editadas anteriormente no Brasil, que conferiam o tratamento de exceção como regra na regulamentação das políticas migratórias brasileiras. Na sua segunda seção, que trata "dos princípios e das garantias", foram inscritos os elementos jurídicos que poderiam representar a quebra desse paradigma, com o repúdio à criminalização da migração, tônica das normas anteriores, além da superação do conteúdo eugenético das leis aprovadas a partir de 1930, melhor 
tradução do biopoder a caracterizar o estado de exceção a que se sujeita o homo sacer. ${ }^{12}$ Ao rejeitar o racismo, a xenofobia e seu efeito discriminatório, a Lei 13.445/2017 (BRASIL, 2017) também deveria promover a entrada regular, a acolhida humanitária, a inclusão social e econômica do imigrante, além de estimular o exercício da cidadania ao garantir sua participação nas causas de seu interesse. Ocorre, entretanto, que tais assertivas formais não correspondem ao contexto internacional contemporâneo e tampouco a uma tradição brasileira, de longa duração, marcada pelo racismo social e institucional que alimenta a opressão, repressão e a eliminação dos vulneráveis. ${ }^{13}$

O fundamento categórico dessa afirmação é o fato de que as normas relativas a estrangeiros editadas no Brasil nos dois últimos séculos consagram os elementos que identificam, em termos modernos, o estado de exceção jurídico, expressos no amplo poder discricionário do Chefe de Estado e do poder Executivo representado por ele, que assumem, em relação aos imigrantes, todas as funções do Estado: a prerrogativa de legislar, executar e decidir sobre a vida dos não nacionais no seu território, encarnando, na esfera do poder político, todos os atributos da soberania.

Na tipificação do estado de exceção contemporâneo, a principal categoria histórica relaciona-se ao protagonismo do Poder Executivo na determinação da "necessidade" de justificar a exceção jurídica, e, a partir daí, na sua prerrogativa de regulamentar e administrar a própria exceção. Em determinadas situações juridicamente declaradas, ou seja, previstas em lei, o Poder Executivo está autorizado a atuar com "plenos poderes" e a "legislar" por meio de regulamentos administrativos "com força de lei" (AGAMBEN, 2007, p. 53-63). ${ }^{14}$

As regulações migratórias no Brasil, especialmente a partir dos anos 1930, são estabelecidas nesses termos, ou seja, por normas que instituem uma situação de exclusão de direitos aos imigrantes, especialmente àqueles considerados legalmente "indesejáveis", destinados, portanto, a uma permanência irregular e precária no território brasileiro, em que o efeito é a subordinação incondicional de seu corpo à exploração econômica, ao aprisionamento e a deportabilidade e a expulsabilidade.

São os paradigmas sobre os quais também se assentou o Estatuto do Estrangeiro (Lei 6.815/80) (BRASIL, 1980), promulgado durante a ditadura civil-militar que governou o Brasil de 1964 a 1985. O diploma, entretanto, apenas reproduz as restrições a direitos editadas ao longo do tempo no Brasil, especialmente durante a ditadura getulista, que governou o Brasil de 1930 a 1945, contexto em que a discriminação adquire um forte conteúdo eugenético inspirado em leis editadas no mesmo período por Estados europeus, o que consagra a instituição, de fato e de direito, da exceção de direitos aos imigrantes indesejáveis.

Segundo Agamben, o estado de exceção evidencia-se quando determinadas medidas jurídicas não se coadunam com o sistema geral de direitos positivados, conferindo forma legal para uma exclusão discriminatória que não poderia ter forma legal. Como efeito, seus destinatários situam-se em uma "zona de indeterminação entre absolutismo e democracia", com status jurídico de semi-sujeitos de direito (AGAMBEN, 2007, p. 13). Para estes, o estado de exceção deixa de ser uma medida provisória e especial aplicada em momentos extraordinários para se tornar paradigma dominante de Estado e técnica permanente de governo. ${ }^{15}$ 
Desde os primórdios do Brasil como Estado soberano, tem sido reservado aos trabalhadores imigrantes, por meio de decretos editados no decorrer do século XIX, um tratamento discriminatório e segregacionista, sujeitando-os ao isolamento e à precariedade da vida nua (AGAMBEN, 1996, 2010), à quebra de contratos e ao endividamento em um contexto em que o tráfico de escravos foi substituído pelo tráfico de imigrantes, sob a responsabilidade do governo, de companhias transportadoras e de proprietários de terras.

A substituição do trabalho escravo pelo trabalho análogo à escravidão, conduta atualmente qualificada como crime tanto pelo direito internacional como interno, desde então está presente nas relações de trabalho no Brasil. Embora não sejam vítimas exclusivas desse sistema contemporâneo de exploração, os imigrantes que não possuem qualificações profissionais especiais estão, invariavelmente, sujeitos tanto no Brasil como em outras partes do sistema-mundo a condições de exploração que caracterizam as formas contemporâneas de escravidão nas relações produtivas.

Tradicionalmente, o regime de exceção recai sobre os denominados "estrangeiros indesejáveis", que, nos termos da Lei 6.815/80 (BRASIL, 1980), são todos os imigrantes que não possuem as qualificações especiais determinadas pelo Conselho Nacional de Imigração (CNIg), órgão administrativo vinculado ao Ministério do Trabalho e Emprego, que tem a função de definir, por meio de Resoluções Normativas com "força de lei", a política migratória do Estado brasileiro.

Em razão desses preceitos normativos, nem mesmo os imigrantes originários dos Estados-Membros e Associados do Mercosul - ou seja, que ratificaram os Acordos de Residência - conseguem, de forma desembaraçada e célere, regularizar seu status jurídico no país, aqui permanecendo, após os dois anos de residência temporária, em situação de irregularidade administrativa, seja pela razão do custo do procedimento, das multas a serem pagas pelo tempo de irregularidade seja pela exigência de prova formal dos meios de subsistência. Essa situação os deixa à margem dos mais elementares direitos civis e sociais.

Historicamente, o estado de exceção ao qual estão submetidos esses imigrantes não configura uma medida excepcional contra estrangeiros, mas uma "técnica de governo" e um "paradigma constitutivo" da ordem jurídica soberana, fundada na suspensão permanente de direitos a uma parcela específica da população residente no território de um Estado Nacional (AGAMBEN, 2007, p. 18).

\section{AINSTITUIÇÃOLEGAL DOS INDESEJÁVEIS EDE SUADEPORTABILIDADE}

Não é recente a percepção de que uma lei de estrangeiros com características discriminatórias traduz um estado de exceção jurídico a eles destinado. A essa constatação chegaram juristas argentinos por ocasião dos debates em torno da Lei de Expulsão, oficialmente denominada de Lei de Residência para Estrangeiros, apresentada ao Senado da Argentina pelo Senador Miguel Cané em maio de 1899. 
Em razão das críticas recebidas por deputados e acadêmicos, a lei somente foi promulgada em 1902, ano em que emergiram movimentos grevistas em diversos setores da economia argentina, culminando com a greve geral do mês de novembro. A partir desses episódios, os imigrantes identificados como líderes do movimento e cujo ingresso, até então, vinha sendo estimulado, deixaram de ser vistos como "trabalhadores laboriosos" e "importantes à civilização" e passaram a ser associados a "elementos indesejáveis" e "perigosos" (DOME$\mathrm{NECH}, 2015)$.

Nesse giro, que coincide com a chegada à América das ideias anarquistas e socialistas que marcaram, no século XIX, o movimento social europeu, a imigração deixa de ser entendida, nos recentes Estados sul-americanos, como necessidade à formação do povo e passa a ser concebida com reservas, pela ameaça que determinados imigrantes representariam às instituições estatais nascentes.

Naquela ocasião, na Argentina, a responsabilidade pelo movimento grevista foi atribuída a italianos e espanhóis identificados como ativistas políticos e sindicais e, portanto, propagadores dos conflitos que resultaram na denominada "questão social argentina" e nas greves de 1902. Após a greve geral de novembro, a Lei de Residência tramitou rapidamente. Aprovada em poucos dias, no terceiro, após sua aprovação, foi declarado o estado de sítio e efetivadas deportações em massa de trabalhadores imigrantes (DOMENECH, 2015).

Durante os primeiros debates parlamentares em torno da Lei de Expulsão até sua aprovação como Lei de Residência, as principais críticas de congressistas e acadêmicos contrários aos seus termos referiam-se, justamente, à ampla discricionariedade conferida ao Poder Executivo nas questões relativas aos estrangeiros. Francisco Durá, afirma "El poder ejecutivo lo es todo en esa ley: fiscal que acusa al extranjero; juez que lo juzga; gendarme que lo prende y expulsa; más aún: el poder ejucutivo mismo define el delito, forma em cada caso la ley que lo declara a los efectos de la penalidade." (DURÁ apud DOMENECH, 2015, p. 184).

Sobre a sessão de votação e debate, Eduardo Domenech descreve:

Entre los que se opusieran, votando en contra, y los que estaban a su favor, pero no la votaron, objetaban a la ley de expulsión, no solo su insconstitucionalidad, sino también el hecho de que fuera una "ley política de excepción" en lugar de una de carácter "permanente", la diferencia que establecía entre nacionais y extranjeros ante la justicia, el uso de la expulsión como un castigo, pena o sanción, y las circusntancias en que se pretendia aprobarla o había sido aprobada (DOMENECH, 2015, p. 185).

Feitas um século antes das conclusões de Giorgio Agamben acerca do biopoder do Estado Nacional sobre a vida nua de pessoas em seu território (AGAMBEN, 1996), as argumentações dos congressistas argentinos traduzem, com exatidão, sua hipótese de que "uma das características essenciais do estado de exceção - a abolição provisória da distinção entre Poder Legislativo, Executivo e Judiciário - mostra [...] sua tendência a transformar-se em prática duradoura de governo." (AGAMBEN, 2007, p. 19). 
O instituto da expulsão do estrangeiro, uma vez instituído pelo Congresso argentino, irá inspirar leis análogas em outros Estados americanos. Na Bolívia, uma Lei de Residência, que reproduz os termos da lei argentina, é promulgada em 1911; no Chile, a lei para evitar a permanência dos extranjeros indeseables e prevenir a chegada de "anarquistas deportados de países vizinhos" foi aprovada em 1918; na Colômbia, a Lei n. 48, de 1920, estabeleceu a proibição de entrada de todos os estrangeiros que proclamassem "el desconocimiento de las autoridades de la República, o el derrocamiento por la fuerza y la violência de su Gobierno"; no Peru, em 1920, e, no Equador, em 1921, foram, igualmente, editadas normas com a idêntica finalidade: restringir a entrada de pessoas que pudessem fazer propagandas de doutrinas políticas ou atentar contra a segurança da República e de suas autoridades (DOMENECH, 2015, p. 178-180). ${ }^{16}$

Ao admitir que o Executivo decrete a ilegalidade da permanência de trabalhadores com determinados posicionamentos políticos em seu território e determine, por meio de procedimentos sumários e a partir de critérios discricionariamente traçados, a saída compulsória e proibição de retorno desses "indesejáveis", consagra-se, na contemporaneidade, a desigualdade de tratamento jurídico entre os nacionais e os não nacionais. ${ }^{17}$

Desde então, os imigrantes passam a ser identificados como "ameaça à segurança nacional" e são associados à perturbação da "ordem pública". O tratamento jurídico a eles conferido é aquele destinado a "pessoas perigosas", o que justificaria as medidas excepcionais que demandam, por sua urgência, as faculdades "extraordinárias" atribuídas ao Executivo e seu braço policial. É justamente nesse contexto que tanto na Europa como na América desaparece a distinção entre função política e função da polícia. ${ }^{18}$

A principal consequência jurídica dessa opção normativa é a criminalização do trabalhador imigrante, como ilustra exemplarmente o recente caso já mencionado da professora italiana Maria do Rosário Barbato, vítima da atuação arbitrária da Polícia Federal brasileira.

Após curto período durante o século XIX em que a imigração é estimulada e a entrada dos imigrantes irrestrita, as leis migratórias brasileiras, desde então, têm presumido essa potencial delinquência dos estrangeiros, identificados, em termos legais, como pessoas passíveis de condutas ofensivas à moralidade, propagadoras de conflitos sociais e propensas à prática de crimes políticos ou comuns. Esses atributos foram expressamente mantidos no Estatuto do Estrangeiro (Lei 6.815/80) e em seu Decreto Regulamentar, vigentes até 30 de novembro de 2017. ${ }^{19}$ Consequentemente, para o Estado brasileiro, os trabalhadores imigrantes têm se constituído, nos termos da lei, como ameaça permanente a justificar o estado policial de controle e as impactantes restrições a direitos fundamentais.

Nessa zona de exceção jurídica, encontra-se o trabalhador sem qualificações específicas, que vem ao Brasil à procura de emprego ou de refúgio, inclusive os originários dos Estados sul-americanos que ratificaram os Acordos de Residência do Mercosul (BRASIL, 2009a), mas também os de nacionalidade haitiana e de Estados africanos, pessoas destinadas a compor a parcela pobre e descartável da população brasileira. 


\section{PRIMÓRDIOSDEUMATRADIÇÃOBRASILEIRA:TRÁFICO,SEGREGAÇÃO E REPRESSÃO}

Os programas oficiais voltados à ocupação do território brasileiro por imigrantes iniciaram-se no século XVIII, no período colonial, com D. João V, e visavam à instalação de colônias agrícolas nas províncias do sul do país: Rio de Janeiro, Espírito Santo, São Paulo e Santa Catarina.

Segundo o Repertório de Legislação Brasileira e Paulista Referente à Imigração (BASSANEZI et al., 2008), o primeiro ato relativo à vinda de migrantes para o Brasil é a Provisão de 9 de agosto de 1747, "que dispunha sobre a condução e o estabelecimento de casais açorianos para essas regiões determinadas." (BASSANEZI et al., 2008, p. 11). O período coincide com a criação, em 1738, da Capitania de Santa Catarina, para onde, de fato, foi conduzida a maior parte das famílias que se dispuseram ao empreendimento (CONEVA, 2009, p. 11-18). Em 31 de agosto de 1746, D. João V aprovou dotação orçamentária que entre os anos de 1747 a 1754 custeou o transporte de cerca de seis mil pessoas (CONEVA, 2009, p. 26-28) das ilhas dos Açores e Madeira até o litoral catarinense (CONEVA, 2009, p. 10) e Rio Grande do Sul.

Cem anos depois desses primeiros atos, pequenas povoações de suíços, alemães, italianos e belgas, assentados em pequenas propriedades, já existiam em rincões isolados do Rio Grande do Sul, Santa Catarina, Espírito Santo, Rio de Janeiro e São Paulo (SEYFERTH, 2011, p. 200).

Vistos como agentes de povoamento e civilização, mas também como ameaça e concorrência aos moradores brasileiros, o governo colonial estimulava as migrações no sul do Brasil como forma de garantir, pelo instituto do uti possidetis, a posse de territórios que caberiam, por tratado, a Espanha.

Em tais circunstâncias, as comunidades migrantes estavam, invariavelmente, destinadas ao isolamento e ao abandono por parte do Estado, ainda em processo de constituição, o que as mantinha afastadas e com necessidade de autogerir uma realidade de privações e dificuldades.

Com a transferência da sede do governo de Lisboa para o Rio de Janeiro e, consequentemente, de sua Corte administrativa, o Decreto de 25 de novembro de 1808 permitiu a concessão de sesmarias a estrangeiros residentes no Brasil. ${ }^{20}$

Até então, a concessão esteve limitada ao "1/4 de légua" de terras concedidas aos casais açorianos, uma dimensão que equivalia cerca de 1,5 km. ${ }^{2}$ Essas propriedades, entretanto, eram ainda menores. Por questão de segurança, as famílias preferiam estar próximas umas das outras e espontaneamente restringiam sua posse. Em outras situações, a falta de pessoas habilitadas a medir os terrenos, "dando menos terra aos açorianos, que foram enganados" (CONEVA, 2009, p. 17-18), também contribuiu para que as expectativas iniciais fossem frustradas. Esses núcleos de colonização eram baseados no cultivo em pequenas propriedades e foram estimulados pelo governo português, sediado no Brasil, nos anos subsequentes. 
No mesmo ano de 1808, com subsídio do governo, 1.500 alemães foram instalados no Espírito Santo. A partir de 1817, são feitas dotações orçamentárias para a instalação de colônias de suíços no chamado Cantão de Fribourg por meio da Carta Régia em 2 de maio de 1818, sucedida por três Decretos: o que vincula a política de povoamento ao Secretário de Estado dos Negócios do Reino, outro que nomeia o Inspetor que acompanharia a instalação das famílias e o terceiro, que regulamenta as condições para seu estabelecimento (BASSANEZI et al., 2008, p. 12).

Após a instalação do Império com a declaração de independência de Pedro I, em 1822, a Lei de 20 de outubro de 1823 autorizou "os presidentes das províncias a promoverem a colonização de estrangeiros nos territórios sob sua responsabilidade." No mesmo ano, pela Decisão Imperial n. 154, de 22 de outubro, foi proibida a aquisição de sesmarias por estrangeiros e a questão sobre concessão de terras foi declarada como sendo de competência da Assembleia Nacional Constituinte (BASSANEZI et al., 2008, p. 12).

$\mathrm{Na}$ transição da administração portuguesa para a brasileira, culminando com a edição da Lei de Terras, de 1850, a imigração buscava, primordialmente, a ocupação e o aproveitamento de terras devolutas e, posteriormente, a substituição do trabalhador escravo pelo imigrante branco. Giralda Seyferth relata:

Na primeira metade do Século XIX, entraram no país cerca de 20 mil estrangeiros, a maioria alemães, que integravam a ocupação de linhas coloniais no Rio Grande do Sul, Santa Catarina, Espírito Santo e Rio de Janeiro, ou as primeiras experiências de contratos de parceria em São Paulo que, além de alemães, incluíram também suíços, portugueses e belgas. A promulgação da Lei de Terras (Lei n. 601, de 1850), (promulgada no mesmo ano em que terminou o tráfico de africanos), consolidou o sistema de colonização baseado na pequena propriedade, mudando a concessão de lotes que passaram a ser por contra, a prazo [...] e nos contratos de parceria, forma de empregar nas fazendas de café trabalhadores europeus, brancos, considerados mais eficientes e racialmente superiores aos negros e mestiços." (SEYFERTH, 2011, p. 200-201).

Em São Paulo, é desse período a primeira iniciativa de criação de colônias agrícolas de imigrantes. A primeira tentativa, em 1827, buscou a instalação de alemães no Núcleo de Santo Amaro, mas fracassou. O projeto só foi retomado em 1874, inspirado na experiência de Curitiba, que, em 1867, instalou 35 núcleos em seu entorno. O êxito dessa experiência animou o governador paulista a promover a criação de colônias com imigrantes italianos e poloneses para cultura da uva e produção de vinho, nos Núcleos Coloniais de São Caetano, São Bernardo, Glória e Santana (ALVES, 2001, p. 53).

Esses primeiros imigrantes, diante de seu isolamento e do abandono do governo, passaram a viver uma situação de penúria, fome e miséria, relatadas de forma circunstanciada nas cartas que enviavam às autoridades do governo paulista e nos relatórios elaborados pelos Engenheiros Chefes dos Núcleos Coloniais, que eram inspetores nomeados para a fiscalização, o controle e a vigilância dos imigrantes em cada colônia instalada em São Paulo. ${ }^{21}$ 
Durante o período da Regência (1831-1840), da renúncia de Pedro I à Declaração de Maioridade de Pedro II, a política migratória passa a ser regulada por lei e fica atribuída às Províncias, nos termos da Lei n. 16, de 12 de agosto de 1834, a responsabilidade compartilhada pela implantação de políticas de ocupação de terras agricultáveis (BASSANEZI et al., 2008, p. 13).

Sucessivamente, são adotadas medidas que irão, efetivamente, estimular a migração, por se tratar, inclusive, de um empreendimento altamente lucrativo para as empresas envolvidas na operação: isenção de impostos para as embarcações que trouxessem "colonos brancos" (Lei n. 99/1935), aumento da dotação orçamentária para "importação de colonos" mediante contratos com companhias comerciais europeias para o estabelecimento de colônias agrícolas no Brasil, e para contratos com companhias brasileiras para captação de trabalhadores na Europa, com descontos nas passagens, que eram subsidiados pelo governo, como forma de minimizar os riscos de prejuízo para as companhias transportadoras e para os imigrantes que financiavam sua viagem (BASSANEZI et al., 2008, p. 13).

De qualquer forma, apesar dos subsídios governamentais, os imigrantes contraiam dívidas com os intermediários e as transportadoras, até mesmo com os fazendeiros que contratavam seus serviços, como evidencia a edição da Lei 108, de 11 de outubro de 1837, que "dá várias providências sobre os contratos de locação de serviços de colonos: busca proteger o colono e encorajar a imigração regulando o contrato que um fazendeiro brasileiro fizesse com um imigrante." (BASSANEZI et al., 2008, p. 14). A situação de endividamento se agrava quando o governo passa, a partir de 1870, a firmar contratos com os próprios fazendeiros, que, a partir de então, tomariam a iniciativa de importação dos trabalhadores que seriam instalados em suas terras (BASSANEZI et al., 2008, p. 14-15; ALVES, 2001, p. 53).

Além dessa dívida privada, os imigrantes também constituíam dívidas com o Estado. Por exemplo, a Decisão 224/1878 estabelece que as passagens que haviam sido concedidas e destinadas ao reagrupamento familiar "não eram gratuitas", e a Decisão 168/1878, que as despesas com documentação deveriam ser pagas pelos imigrantes (BASSANEZI et al., 2008, p. 19). Nesse sentido, destaca-se que a Decisão $465 / 1874$ já havia determinado que os títulos definitivos de propriedade "só seriam entregues aos colonos quando tivessem saldado suas dívidas com a Fazenda Nacional” (BASSANEZI et al., 2008, p. 18), o que poderia retardar a tradição definitiva da terra ao imigrante.

Os imigrantes que chegaram ao Brasil durante o Império vinham atraídos por uma eloquente propaganda governamental feita pelos escritórios consulares na Europa ou pelas companhias privadas contratadas para esse fim. Quando chegavam, eram destinados a locais predeterminados e deveriam, inicialmente, trabalhar na formação do núcleo colonial, derrubando matas, abrindo estradas, construído benfeitorias, além da obrigação de lavrar a terra.

Para esse trabalho, poderiam receber, durante um ano, um salário do governo provincial, quando vinham para o Brasil às suas próprias expensas. Quando as passagens eram subsidiadas pelo governo local, nada recebiam pelas obras públicas que deveriam realizar (ALVES, 2001, p. 56-57). 
Esse acúmulo de atribuições delegadas aos imigrantes levava, invariavelmente, ao fracasso do projeto agrícola. Transcorrido o primeiro ano, quando cessavam os subsídios governamentais, os imigrantes eram abandonados no seu isolamento sem condições mínimas para estabelecer-se economicamente, frustrando o projeto inicial.

Passavam, então, pelas mesmas privações da população pobre originária, vivendo basicamente da extração e venda de madeira nativa, e por isso passaram a ser alvo de discriminação, identificados como "indolentes", "ignorantes", "atravessadores", "insubmissos", "desordeiros e vadios", em face do insucesso dos núcleos (ALVES, 2001, p. 67-68, grifo do autor). ${ }^{22}$

No imaginário da elite brasileira, foi se constituindo um temor em relação ao imigrante, e essa discriminação adquire forma jurídica na Decisão n. 47, de 28 de janeiro de 1879, que "proíbe imigrantes que vivem nos núcleos coloniais de se dirigirem à Corte, qualquer que seja o motivo" (BASSANEZI et al., 2008, p. 30), o que evidencia que aos imigrantes residentes no Brasil, trabalhadores importados por contratos com empresas privadas, era dispensado um tratamento excepcional em relação aos demais trabalhadores pobres residentes no país.

Além do tráfico e, consequentemente, da constituição de dívidas seja com o governo, agentes intermediários, transportadoras seja com os fazendeiros, o que impedia o imigrante de adquirir definitivamente a terra ou prendendo-o a ela; além do isolamento e da precariedade material em que viviam, que, mais tarde, na República, viria justificar as intervenções militares nas colônias consideradas "quistos não assimiláveis" e, portanto, "ameaça à integridade nacional” (SEYFERTH, 2011, p. 203); outro aspecto de exceção a caracterizar a política migratória brasileira é a atribuição do controle migratório à força policial, o que ocorre desde 1817, no período de Reino Unido a Portugal, mediante a Portaria de 8 de fevereiro, que "recomenda providências à Polícia acerca dos estrangeiros que entram no Reino" (BASSANEZI et al., 2008, p. 12). Desde então, tem-se mantido, no trato com os imigrantes, essa tradição persecutória, repressiva e criminalizante, que a Lei de Migração parece não superar.

Essa tradição, que faz da imigração uma "questão de polícia", ao considerá-la potencialmente ameaçadora à estabilidade social, à segurança e à integridade nacional, constrange, a partir do Estado Novo, o novo imigrante a uma situação de "ilegalidade" juridicamente condicionada, que o oprime psicológica e fisicamente. Quanto ao velho imigrante, às políticas de imposição do "espírito nacional". Desde então, pelas leis brasileiras, qualquer trabalhador imigrante seria passível de prisão para efeito de deportação, ao incidir em qualquer irregularidade administrativa, ou passível de expulsão, por infração de norma penal ou de disposições especiais, nas leis migratórias e que determinam tal medida extraordinária, o que configura uma situação de permanente instabilidade e risco para o estrangeiro. ${ }^{23}$

O fato é que não se reconhece, juridicamente, o ato de migrar como um direito fundamental da pessoa, globalmente entendido como fenômeno a ser regulado e controlado pelo Estado, que tem competência exclusiva para determinar, circunstancialmente, quais são os imigrantes "desejáveis" e os "indesejáveis", em razão de seus interesses e da segurança nacional. Tal prerrogativa é reconhecida, inclusive, por tratados de direitos humanos. ${ }^{24}$ 
Consequentemente, o trabalhador imigrante, para a ordem jurídica nacional, permanece como objeto de controle e fiscalização do Estado, ao invés de sujeito destinatário de direitos plenamente reconhecidos.

\section{A DECLARAÇÃO DOS “INDESEJÁVEIS” NA PRIMEIRA REPÚBLICA}

Durante a Primeira República no Brasil (1889-1930), houve forte estímulo aos fluxos migratórios, com dotações anuais da União aos Estados e dos próprios Estados às empresas transportadoras para o subsídio de passagens, agasalhos e instalação de imigrantes em núcleos agrícolas. Em São Paulo, decretos estaduais fixavam, anualmente, o número de imigrantes que deveriam chegar mediante subsídios governamentais. ${ }^{25}$

Apesar disso, a primeira Constituição republicana, de 24 de fevereiro de 1891, notabilizou-se por medidas que seriam consideradas, posteriormente, como repressivas e violadoras de direitos, como a que estabeleceu "a grande naturalização", ou seja, a naturalização compulsória de todos os estrangeiros residentes no Brasil até 15 de novembro de 1891, data da Proclamação da República, que não declarassem, no prazo de seis meses após a vigência da Constituição, sua vontade de manter a nacionalidade de origem. ${ }^{26} \mathrm{~A}$ Emenda Constitucional de 3 de setembro de 1926 alterou o art. 72 para estabelecer, no seu parágrafo 33, a permissão ao Poder Executivo para expulsar os estrangeiros considerados “perigosos à ordem pública ou nocivos aos interesses nacionais". Termos que viriam a ser repetidos em todas as demais normas posteriores, até o Estatuto do Estrangeiro recentemente revogado.

Começa a se delinear, juridicamente, os contornos da imigração indesejável e os meios institucionais de promoção da ilegalidade do imigrante, excluindo-o da proteção jurídica e ensejando sua saída compulsória do território.

Nesse aspecto, destaca-se que mulheres e crianças desacompanhadas de seus maridos ou pais, desde o início das políticas de povoamento, eram rejeitadas pelos programas governamentais e sofriam as consequências opressivas que decorriam de sua indesejabilidade. É o que aferimos na carta que denuncia a postura do engenheiro fiscalizador contra uma viúva e seus filhos ao recusar-lhes os subsídios pagos pelo governo aos homens, o que levou a família à miséria. ${ }^{27}$ Em março de 1892, Decreto presidencial autorizou a repatriação de viúvas e órfãos de imigrantes falecidos no Brasil. Na capital paulista, o Decreto de 1908 criou, junto à Hospedaria dos Imigrantes, uma creche/asilo para abrigo de órfãos. Indesejáveis também eram os homens maiores de 45 anos, por não serem considerados aptos a trabalhar. No estado de São Paulo, em 1916, esse limite foi ampliado para 50 anos. ${ }^{28}$

No ano seguinte à promulgação da Constituição republicana, a Lei n. 97, de 5 de outubro de 1892, permitiu a livre entrada de imigrantes chineses e japoneses no Brasil. Entretanto, a imigração de orientais seria, posteriormente, veementemente combatida por autoridades brasileiras. ${ }^{29}$ 
Por meio do Decreto n. 4.247, de 5 de janeiro em 1921, "que regula a entrada de estrangeiros no território nacional”, o Governo Federal estabeleceu pela, primeira vez, seguindo a tendência de outros Estados americanos, limites ao ingresso de imigrantes, restringindo o acesso a todos aqueles considerados "perniciosos à ordem pública e à segurança nacional" (BASSANEZI et al., 2008, p. 66) . ${ }^{30}$ Da mesma forma, cuidou, com indisfarçável viés eugenético, do impedimento de entrada de portadores de moléstias físicas e mentais, de deficientes físicos, e também de maiores de 60 anos e de toda estrangeira que pudesse "entregar-se à prostituição". O seu art. $2^{\circ}$ relaciona os casos de expulsão, que, entretanto, só deveriam se efetivar se o imigrante estivesse no Brasil há menos de cinco ano. ${ }^{31}$ Caso o imigrante fosse objeto de pedido de expulsão, o procedimento seria administrativo, requerido junto ao Ministério da Justiça, e o imigrante, não saindo espontaneamente do território nacional no prazo estipulado, deveria ser recolhido, indefinidamente, à prisão especial. Uma vez expulso, não poderia retornar ao Brasil, pois sua volta configuraria crime contra a ordem social.

Os mesmos termos foram recepcionados pelo Estatuto do Estrangeiro, ${ }^{32}$ e o Código Penal brasileiro tipifica como crime o retorno do imigrante expulso. ${ }^{33}$

\section{AS POLÍTICAS EUGENISTAS DOS GOVERNOS DE GETÚLIO VARGAS}

A política de discriminação de estrangeiros iniciada na década de 1920 foi aprofundada nos governos de Getúlio Vargas (1930-1945), período em que a política relativa a estrangeiros concentrou-se em estabelecer critérios ao controle de entrada e realizar intervenções junto às comunidades de imigrantes estabelecidos, mas considerados refratários à assimilação nacional (SEYFERTH, 2011, p. 219). Foram editadas, nesse período, diversas normas restritivas a caracterizar o "estado de exceção" como paradigma de governo em relação aos imigrantes indesejáveis, conforme, décadas antes, fora constatado por deputados argentinos.

Dentro do espírito do Decreto 4.247/1921 (BRASIL, 1921), é instituído o Decreto 19.482/1930 (BRASIL, 1930), pelo qual o Brasil passa a controlar o ingresso de "passageiros de terceira classe", justificando tal medida como necessária à "proteção ao trabalhador nacional.” A decisão prenunciava outras normas de conteúdo restritivo que a sucederiam e que, posteriormente, seriam recepcionadas pelo Estatuto do Estrangeiro.

O viés discriminatório dessa norma é proclamado logo no seu preâmbulo, que considera "[...] que uma das causas do desemprego se encontra na entrada desordenada de estrangeiros, que nem sempre trazem o concurso útil de quaisquer capacidades, mas frequentemente contribuem para aumento da desordem econômica e da insegurança social" (BRASIL, 1930, online, grifo nosso), consagrando, desde então, a principiologia inscrita no Estatuto do Estrangeiro: proteção à segurança nacional e ao trabalhador brasileiro. ${ }^{34}$

O Decreto 19.482/1930 (BRASIL, 1930), ao estabelecer que os subsídios aos imigrantes recém-chegados e estabelecidos nos núcleos de colonização seriam destinados apenas aos "trabalhadores constituídos em família" (art. $7^{\circ}$ ) ${ }^{35}$, não se furta em ditar padrões morais 
a um propósito que é, essencialmente, econômico. Posteriormente, o Decreto 24.258, de 16 de maio de 1934, definiria uma família de imigrantes, ao determinar a necessidade de, no mínimo, "a existência de duas pessoas, maiores de 12 anos e menores de 60, aptas para o trabalho agrícola" (BRASIL, 1934a, online, grifo nosso)..$^{36}$

Este último regulamenta o Decreto n. 24.215, de 9 de maio de 1934 (BRASIL, 1934b), ${ }^{37}$ que veio ampliar o rol de proibições de entrada de estrangeiros incluindo nômades, ciganos, analfabetos ou pessoas "com costumes manifestamente imorais", o que abre uma larga margem de discricionariedade para as autoridades estatais no impedimento de entrada de imigrantes. ${ }^{38}$ Seu decreto regulamentar, supramencionado, ainda determina que, para o estrangeiro entrar no país de forma regular, ele necessita ser "chamado" pelos governos estaduais, por familiares já estabelecidos, por empresas ou proprietários de terras, sempre mediante prévia autorização conferida pelo Ministério do Trabalho, Indústria e Comércio. ${ }^{39}$ Esses critérios foram mantidos pelo Estatuto do Estrangeiro revogado pela Lei de Migração.

Todas essas medidas restritivas têm o efeito jurídico de promover a ilegalidade e instituir a figura do imigrante irregular, até então inexistente no ordenamento jurídico, submetendo o trabalhador a uma condição permanentemente precária e deixando-o absolutamente entregue à discricionariedade estatal, que o situa à margem de uma proteção legal efetiva. Nesse sentido, constituem normas de exceção, uma vez que sua aplicação restringe a incidência das leis que estabelecem direitos. Estas, sob o fundamento do "estado de necessidade", são suspensas em relação a um grupo específico, os imigrantes, juridicamente considerado potencial ameaçador às instituições estatais e os trabalhadores nacionais. ${ }^{40}$

Como resultado, o sistema ordinário de direitos não é aplicável aos imigrantes indesejáveis, consequentemente irregulares. Enfim, todos aqueles que não são "chamados" a virem ao Brasil, mas que, espontaneamente, para cá se dirigem em busca de trabalho.

Logo após a promulgação da Constituição de 1934, foi aprovada, no mesmo ano, uma Emenda Constitucional ao seu art. 121, que ficou conhecida como Lei de Cotas. A Emenda veio ao encontro do discurso proferido por Getúlio Vargas por ocasião da instalação da Assembleia Constituinte, em 1933, quando sinalizou que "a política migratória flexível", adotada até então, seria substituída pela "restrição à livre entrada de imigrantes" (VARGAS, 1934, p. 115-120). Vargas, entretanto, não deixou de reconhecer em sua fala a importância da imigração para o desenvolvimento econômico, em face da permanente necessidade "de braços fortes e adestrados" e de ocupação do território (GERALDO, 2009, p. 178).

A Lei de Cotas foi resultado de amplos debates parlamentares sobre o tema migratório. Nas sessões legislativas, foram proferidos discursos que defendiam com veemência a implantação de medidas racistas, repressivas e de restrição a direitos, em um contexto marcado pelos debates junto ao I Congresso Brasileiro de Eugenia, em 1929, acerca de "critérios raciais para exclusão de etnias indesejáveis, alertando para os 'perigos da migração promíscua sob o ponto de vista dos interesses de raça e da segurança política e social da República.'” (SEYFERTH, 2011, p. 204). 
O principal efeito da Lei de Cotas foi ampliar a relação de "indesejáveis", para evitar a entrada de analfabetos e, especialmente, de não brancos, ou seja, africanos, árabes e orientais. Além do conteúdo racial, a eugenia era reforçada pela proibição da entrada de pessoas com problemas de saúde mental (BRASIL, 1934a).

Estabelecia-se, enfim, nas palavras do deputado cearense Xavier de Oliveira, um novo critério, "nacionalista, antropológico e eugenético", a orientar uma política migratória afinada com as tendências racistas e higienistas europeias (GERALDO, 2009, p. 177-185).

Como resultado desse pensamento, foi editado o Decreto-Lei n. 406, de 4 de maio de 1938 (BRASIL, 1938a), que continuou a ampliar as restrições de entrada, da mesma forma que aumentava o poder discricionário do Poder Executivo na instituição de outros limites de ingresso e de permanência de estrangeiros, ao estabelecer as medidas obrigatórias de assimilação especialmente nas comunidades de imigrantes alemães e japoneses.

O parágrafo único do seu artigo $1^{\circ}$ estabeleceu que as circunstâncias impeditivas à entrada eram meramente enunciativas, consagrando o princípio da expectativa de direitos, em relação ao estrangeiro. No art. $2^{\circ}$ vem o preceito segundo o qual "o Governo Federal reserva-se o direito de limitar ou suspender, por motivos econômicos ou sociais, a entrada de indivíduos de determinadas raças ou origens, ouvido o Conselho de Imigração e Colonização." (BRASIL, 1938a, online). ${ }^{41}$

O Decreto-Lei 406/38 foi complementado pelo Decreto-Lei n. 479, de 8 de junho de 1938 (BRASIL, 1938b), que dispôs sobre a expulsão dos estrangeiros, enumerando os atos de nítido conteúdo político-social, que poderiam levar o imigrante à prisão e à retirada compulsória do território nacional: atentar contra a dignidade da Pátria e contra a propriedade e segurança no trabalho, ser considerado elemento pernicioso pela polícia de outro país ou tiver sido expulso de outro país, entrar no Brasil de forma irregular ou quando perturbar o livre funcionamento de associações profissionais.

Essas medidas eram dirigidas, especialmente, às comunidades migrantes estabelecidas no Brasil e que viviam, até a década de 1930, em isolamento, até que se iniciaram as medidas de assimilação nacional. A partir de então, estavam sujeitas a intervenções militares, com controle permanente do exército sobre o conteúdo ministrado em suas escolas e reportado pelos jornais locais. O DL 406/38, no seu capítulo VIII, cuida, justamente, das medidas assimilacionistas, que retratam mais um exemplo de política de exceção e discriminação contra imigrantes no Brasil..$^{42}$

\section{O ESTATUTO DO ESTRANGEIRO, O ESTADO DE EXCEÇÃO E A NOVA LEI DE MIGRAÇÃO}

O Estatuto do Estrangeiro, promulgado em 1980, reedita, em um contexto nacional igualmente totalitário e centralizador que coincide, em âmbito internacional, com a Guerra Fria, as mesmas normas de caráter excepcional editadas durante o Estado Novo: a defesa da segurança nacional e dos trabalhadores brasileiros. Para tanto, a Lei 6.815/80 (BRASIL, 
1980) confere ampla discricionariedade ao Estado, consagrando o protagonismo do Poder Executivo na edição de normas migratórias “com força de lei”, aspecto característico, segundo Agamben, do estado de exceção (AGAMBEN, 2007, p. 54-63). ${ }^{43}$

A regulação da política migratória brasileira é traçada por meio de Resoluções Normativas editadas pelo Conselho Nacional de Migração (CNIg), instituído pelo Estatuto do Estrangeiro e mantido pela lei recém promulgada. ${ }^{44}$

O CNIg está vinculado ao Ministério do Trabalho e Emprego, que, por meio da Coordenação Geral de Imigração (CGIg), é igualmente responsável pela emissão da autorização de trabalho ao estrangeiro a condicionar os vistos emitidos pelos consulados brasileiros. Suas Resoluções Normativas substituem os Decretos-Lei do período autoritário precedente e podem ampliar ou flexibilizar os impedimentos relativos aos trabalhadores sem qualificações específicas, pois as normativas atenderão aos interesses e aos projetos do governo do momento, de acordo com as circunstâncias internas e internacionais que definirão a política relativa à imigração, sem qualquer garantia de estabilidade ou previsibilidade para os imigrantes.

O controle do seu cumprimento e, portanto, da entrada e permanência do imigrante no território brasileiro é feito, da mesma forma que no passado colonial, por autoridades policiais, no caso, a Polícia Federal, coordenada pelo Ministério da Justiça.

O Estatuto do Estrangeiro e o seu Decreto regulamentador (Decreto 86.715/1981) (BRASIL, 1981) recepcionam os paradigmas migratórios estabelecidos na Primeira República e no período dos governos de Getúlio Vargas: concentração no Poder Executivo das competências normativas, fiscalizadoras, jurisdicionais e sancionatórias em relação aos imigrantes; seletividade na entrada; discricionariedade na decisão sobre permanência; presunção do estado de necessidade e de defesa em relação ao estrangeiro, e de que sua presença no território nacional seja vista como potencial ameaça à segurança do Estado ou ao emprego dos brasileiros.

Como regra, apenas trabalhadores com qualificações específicas previamente chamados por empresas nacionais ou estrangeiras aqui sediadas têm garantida a sua acolhida pelo CGIg, obtendo o visto de entrada e registro junto ao Ministério da Justiça. ${ }^{45} \mathrm{O}$ Acordo de Residência do Mercosul flexibiliza essa regra ao admitir a residência temporária no país de destino por dois anos, tempo para que trabalhador originário dos Estados signatários possam se estabelecer economicamente e demonstrar, formalmente, meios suficientes de subsistência, seja pela abertura de uma empresa seja por contrato regular de trabalho. Se não estiverem presentes tais condições, o trabalhador imigrante, nos termos de uma secular tradição jurídica, incide em irregularidade, condição suficiente para alijá-lo ou restringir-lhe o acesso ao sistema de direitos conferidos aos nacionais.

O princípio da ampla discricionariedade estatal em relação aos imigrantes atua em detrimento da exigência constitucional da legalidade estrita para os atos do Executivo, ampliando as matérias de competência privativa dos entes administrativos, o que confere uma permanente insegurança aos trabalhadores estrangeiros no Brasil, que nunca terá consolidado seu direito à permanência, que será sempre precário. Um dos efeitos jurídicos dessa política 
é a impossibilidade de os imigrantes aperfeiçoarem direito líquido e certo à permanência, o que restringe de forma significativa a utilização de remédios constitucionais, como o Habeas Corpus e o Mandado de Segurança em defesa do imigrante. O estrangeiro no Brasil, a critério do Estado, sempre estará passível de deportação. Nos termos da Lei 6.815/80 (BRASIL, 1980), estava, inclusive, sujeito à prisão, sem que tivesse praticado qualquer fato delituoso. ${ }^{46}$

A nova Lei de Migração, embora tenha estabelecido o princípio da não criminalização do imigrante (art. $3^{\circ}$, III) ${ }^{47}$ e restringido as possibilidades de sua prisão, manteve, integralmente, sua possibilidade, desde que submetida à Justiça Federal.

Assim, além da detenção do imigrante nas áreas de fiscalização dos portos e aeroportos, para efeito de repatriação, ${ }^{48}$ a prisão é igualmente possível, quando o imigrante é residente irregular. É o que se depreende do art. 48 ao prever que, nos "casos de deportação ou expulsão, o chefe da unidade da Polícia Federal poderá representar perante o juízo federal" (grifo nosso). A representação perante o juízo foi estabelecida ainda na vigência da Lei 6.815/80 (BRASIL, 1980), que previa a possibilidade de prisão administrativa para efeito de deportação. Sua inconstitucionalidade foi reconhecida em face da competência exclusiva do Judiciário, nos termos do art. 5, LXI, da Constituição de 1988, para qualquer decisão relativa à privação da liberdade.

Embora dirimida a ampla discricionariedade do Estado, com a previsão do legal do controle do Poder Judiciário sobre questões migratórias, o paradigma jurídico da segurança nacional e proteção ao trabalhador brasileiro estão implícitas na Lei de Migração, como vinham explicitadas pelo Estatuto do Estrangeiro e pelas normas que o antecederam.

A nova lei, ao prever a existência dos meios de saída compulsória, acompanha a racionalidade jurídica dos diplomas anteriores ao instituir, juridicamente, o indesejável e sua proibição de entrada, a entrada irregular e sua deportabilidade. A zona de exceção de direitos permanece bem como o paradigma jurídico da discriminação em relação aos primeiros e elementares dispositivos da Constituição Federal, que consagram a dignidade da pessoa humana e o valor social do trabalho (art. $1^{\circ}$ ) como condições para a construção de uma sociedade "livre, justa e solidária", capaz de garantir o desenvolvimento, o combate à pobreza, à marginalização e à discriminação de qualquer natureza (art. $\left.3^{\circ}\right)$.

São normas fundamentais que não comportam tratamento diverso a pessoas que trabalham nas mesmas condições que o trabalhador nacional, que residem no território brasileiro e aqui estabelecem suas relações pessoais da mesma forma que os nacionais. Como pessoas que são, não se justificaria a exceção a que estão submetidos, a não ser sob a condição de homo sacer modernos (AGAMBEN, 2007, 2010).

\section{CONCLUSÃO}

Nos últimos anos, especialmente nos governos de Dilma Rousseff, foram notáveis as iniciativas tendentes a superar os paradigmas discriminatórios e excludentes estabelecidos pela tradição normativa brasileira em relação aos imigrantes. 
Nesse período (2010-2016), tais paradigmas foram flexibilizados com a introdução, por meio de resoluções normativas, de critérios humanitários no trato conferido a imigrantes no Brasil. Foram, igualmente, desenvolvidas políticas de estímulo à recepção digna de integração ao mercado de trabalho e participação política em questões de seu interesse. Foi o que ocorreu com as audiências públicas e consultas que culminaram com as conferências realizadas no âmbito da COMIGRAR.

Como resultado desses esforços, foi aprovada a Lei de Migração, mas com 21 vetos, todos relativos à proteção de direitos, o que fez prevalecer, em relação aos imigrantes, a mera expectativa de direitos e a mesma estrutura institucional da lei anterior, baseada nos interesses nacionais e discricionariedade do Estado.

Conforme reiterado pelos imigrantes em audiências públicas e conferências da COMIGRAR, o protagonismo conferido e mantido pela Lei de Migração à Polícia Federal dificulta o cumprimento dos Acordos de Residência do Mercosul e Estados Associados e, inclusive, da Lei de Refúgio, mesmo que a polícia não tenha em relação aos refugiados a atribuição de decidir sobre quem pode entrar, mas apenas autorizar sua residência quando solicitado, até seu reconhecimento pelo Conselho Nacional para Refugiados (CONARE), único órgão com capacidade decisória sobre pedidos de refúgio. ${ }^{49}$

A Polícia Federal, além de ser a polícia de fronteira, conforme declarado na Lei de Migrações. Em relação aos imigrantes, tem tido tradicionalmente o papel de polícia política e social. Especializada no combate à criminalidade, essa atuação, condicionada pelas práticas e pela tradição discriminatória, leva a práticas que criminalizam o trabalhador imigrante.

Portanto, as iniciativas tendentes a instituir um novo marco migratório brasileiro para migrações, rompendo com uma tradição jurídica fundada na discriminação dos não nacionais, enfatizada pela disputa ideológica expressa nas grandes guerras do século XX e na Guerra Fria, o que leva os Estados a decidirem sobre quem é ou não nacional e quem é ou não digno de viver ou estar em seu território, podem ter sido apenas um soluço democrático em um contexto interno e internacional que remete à necessidade de defender a segurança nacional da "ação de terroristas" e o emprego dos brasileiros diante da "crise econômica."

A constituição histórica do povo brasileiro e a ocupação do território deram-se em razão da imigração voluntária ou forçada, que resultou em trezentos anos de trabalho escravo. Apesar do argumento civilizatório em relação aos imigrantes europeus, nas políticas migratórias do século XIX, não temos tradição de boa acolhida e de reconhecimento de direitos ao migrante internacional. Desde então, o trabalhador estrangeiro tem sido vítima do agenciamento por terceiros, de promessas governamentais não cumpridas, da discriminação em relação aos nacionais na aferição de direitos, fatores que precarizam suas condições de existência.

Condições que deveriam ser superadas em um contexto mundial que promove crises recorrentes e em que os deslocamentos são estimulados por tecnologias que encurtam distâncias e promovem comunicação, fatores que viabilizam o projeto migratório e conferem 
ao imigrante maior segurança em buscar destinos que possam lhe oferecer condições de sobrevivência ou satisfatórias de vida.

As guerras que se prolongam em diversas regiões da África e do Oriente Médio, as crises políticas provocadas na América Central e do Sul, catástrofes ambientais e demandas promovidas por crises econômicas cíclicas e geograficamente condicionadas pela divisão internacional da produção promovem alguns Estados como destino migratório e outros, por outro lado, tendentes a promover a saída de seus nacionais.

Entretanto, a manutenção de paradigmas autoritários, mesmo que estes sejam incompatíveis com o sistema internacional e constitucional de direitos humanos, é compatível com interesses econômicos que comportam e estimulam a figura jurídica do "imigrante irregular", trabalhador situado na zona de exceção a direitos e na esfera de indignidade dirigida ao homo sacer, o que o torna vítima de novas formas de trabalho escravo que tem vitimado imigrantes em todo o mundo.

Por isso, a nova Lei de Migração, fruto do trabalho de especialistas em direitos humanos e das recomendações democraticamente propostas nos fóruns de consulta, tem grande possibilidade de não romper com os tradicionais paradigmas migratórios de suas antecedentes.

Seja pela racionalidade do sistema mundial de soberanias acerca das questões migratórias, política que tem resultado na propagação de campos de concentração, na figura de campos de refugiados, seja pela tradição jurídica interna de exceção, que tem marcado as questões migratórias no Brasil, o que resultou da Lei 13.445/2017 (BRASIL, 2017) foi ratificação do controle da regularidade migratórias nos postos de entrada, a expectativa de direito em relação à entrada e à permanência, a possibilidade de detenção e prisão dos imigrantes irregulares nos postos de entrada ou após ingressarem no território brasileiro, o controle policial de entrada e permanência, e seu componente criminalizador, além de todos os meios de saída compulsória presentes desde as primeiras leis migratórias instituídas no início do século XX, denunciadas pelos juristas liberais do período por serem "leis de exceção."

\title{
MIGRATION POLICIES AND THE LEGAL PRODUCTION OF "THE UNWANTED”: A HISTORIC STATE OF EXCEPTION FOR FOREIGNERS IN BRAZIL
}

\begin{abstract}
The participation of immigrants in the I Conference on Migration and Refugee resulted in a detailed portrait on the situation of restriction of rights to which they are subject in Brazil. It was also pointed out that such barriers are a consequence of institutional rules and practices rooted in the Brazilian bodies responsible for migratory issues. The recommendations presented at the conference contributed to the enactment of Law 13,445/2017, which established the new Migration Law. Stemming from an ethnographic work that was carried out alongside
\end{abstract}


COMIGRAR, this article involves an exploratory study of the decrees related to migration edited from the monarchical period and onward, during the government of Getulio Vargas, until the recently revoked Foreigner Statute. This approach allows us to assess a tradition of discriminatory behavior that has led to the precariousness of the condition of foreign workers in Brazil. According to the concepts formulated by Giorgio Agamben regarding homo sacer and the modern state of exception, the author intends to demonstrate that such historical path crystallizes official discriminatory and restrictive practices against the rights of migrants, which could compromise the humanistic paradigm of the new legal diploma.

Keywords: Discrimination. State of exception. Homo sacer. Immigration. Migration Law

\section{POLÍTICAS MIGRATÓRIAS EN BRASIL Y LA INSTITUCIÓN DE LOS "INDESEADOS": LA CONSTRUCCIÓN HISTÓRICA DE UN ESTADO DE EXCEPCIÓN PARA EXTRANJEROS}

\section{RESUMEN}

La participación de los inmigrantes en la I Conferencia sobre Migración y Refugio resultó en un levantamiento circunstanciado de la situación de restricciones a derechos a que están sujetos en Brasil. Se evidenció también que tales restricciones son consecuencia de normas y prácticas institucionales arraigadas junto a los órganos brasileños responsables por el control migratorio. Las recomendaciones presentadas por los inmigrantes en el ámbito de la conferencia contribuyeran para la edición de la Ley 13.445/2017, llamada Ley de Migración. A partir del trabajo etnográfico realizado junto a COMIGRAR, este artículo se dedica a un estudio exploratorio relativo a los decretos migratorios editados desde el periodo monárquico, pasando por el período del gobierno de Getúlio Vargas y sus políticas higienistas e eugenésicas, hasta el recién revocado Estatuto del Extranjero. El abordaje tiene como objetivo evidenciar una tradición discriminatoria que tiene llevado a la precarización del trabajo del extranjero en Brasil. De acuerdo con los conceptos formulados por Giorgio Agamben a respecto del homo sacer y del estado de excepción en la modernidad, se procura demostrar que tal recorrido histórico cristaliza prácticas oficiales restrictivas a derechos, lo que puede comprometer el paradigma humanista de la nueva Ley de Migración.

Palabras-clave: Discriminación. Estado de excepción. Homo sacer. Inmigración. Ley de Migración.

1 Foram submetidos ao Congresso Nacional dois projetos de lei revogadores do Estatuto do Estrangeiro (Lei 6.815/1980), o PL 5655/2009 e o PL 2516/2015, que seguiram apensados a outros afins, sobre a mesma matéria, até a declaração de prejudicialidade. O último resultou na aprovação da Lei de Migrações, em 24 de maio de 2017, embora com diversos vetos e disposições com eficácia contida, a dependerem de decreto presidencial re- 
gulamentador. A curiosidade em relação ao projeto 2516/2015 é que é originário do Senado Federal, onde fora apresentado pelo Senador Aloysio Nunes, Ministro das Relações Exteriores, que, entretanto, foi incapaz de evitar sua descaracterização pelos vetos interpostos.

2 O processo de consulta promovido por órgãos do Ministério da Justiça resultou, inicialmente, no Projeto de Lei 5655/2009, submetido a audiências públicas para sua elaboração. Esse projeto, declarado prejudicado em face do PL 2516/2015, estabelecia um novo Estatuto do Estrangeiro, terminologia que indicava, de pronto, sua natureza discriminatória. Em 2013, a Portaria n. 2.162, do Ministério da Justiça, criou a Comissão de Especialistas para elaboração de um Anteprojeto de Lei de Migrações pautado em direitos humanos, que foi, igualmente, submetido a audiências públicas. Finalmente, de outubro de 2013 a maio de 2014, fóruns de debates foram promovidos nas principais cidades brasileiras de destino migratório como parte da I Conferência Nacional sobre Migração e Refúgio. A conferência final foi realizada na cidade de São Paulo, com plenária nacional formada por delegados indicados nos fóruns parciais de discussão. Esses delegados nacionais debateram, de 30 de maio a $1^{\circ}$ de junho de 2014, propostas para uma nova política migratória no Brasil, que, em grande medida, foram recepcionadas pela Lei de Migrações (Lei 13.445/2017).

3 O Acordo de Residência do MERCOSUL e Estados Associados está vigente no Brasil desde a promulgação do Decreto de ratificação n. 6.975, de 7 de outubro de 2009 (BRASIL, 2009a).

4 Todas essas entidades colaboraram com a redação da nova lei apresentando normas técnicas, no processo de tramitação do PL 2516/2015 no Congresso Nacional, com propostas de alteração do texto apresentado e aprovado pelo Senado, de forma a adequá-lo a uma lei migratória que efetivamente superasse princípios discriminatórios e criminalizantes do Estatuto do Estrangeiro pela incorporação de princípios promotores de direitos humanos e do trabalhador imigrante e sua família.

5 Maria do Rosário Barbato, de nacionalidade italiana, possui cargo efetivo de Professora Adjunta na Faculdade de Direito da Universidade Federal de Minas Gerais (UFMG), onde ministra aulas de Direito do Trabalho. Em março de 2016, foi instaurado inquérito contra a professora na Superintendência da Polícia Federal de Minas Gerais com fundamento no Art. 125, inciso XI, c/c Art. 128 da Lei 6.815/80 (BRASIL, 1980), que remetem ao Código de Processo Penal à violação do Art. 106, inciso VII, da mesma lei, ou seja, "participar da administração ou representação de sindicato ou associação profissional". A conduta é apenada com detenção de 1 (um) a 3 (três) anos e expulsão. Apesar da restrição do Estatuto do Estrangeiro, a sindicalização é garantida pelo Art. $8^{\circ}$ da Constituição brasileira, além da livre manifestação do pensamento constituir um dos direitos consagrados pelo Art. $5^{\circ}$ da CF. Diante da instauração do inquérito e da forma arbitrária de intimação da investigada, feita com determinação para que o Reitor da UFMG conduzisse a docente à sede da Polícia, o próprio Ministério Público Federal ajuizou Habeas Corpus em favor da professora, prontamente acolhido e deferido pela Justiça Federal, que não só determinou a extinção do Inquérito Policial 0310/2016-4SR/DPF/MG como concedeu liminar para a suspensão de todos os atos correlatos a ele (BRASIL, 2016).

6 A expressão Modern World-System foi cunhada por Immanuel Wallerstein para designar o modelo capitalista de produção. Sua tese pode ser encontrada nos quatro volumes que compõem a obra Sistema-Mundo Moderno.

7 Segundo Agamben, em referência a Walter Benjamin, "a tradição dos oprimidos nos ensina que o estado de exceção no qual vivemos é a regra" (AGAMBEM, 1996, p. 6), e seu sujeito é o homo sacer, ou aquele que foi banido, "que não é, simplesmente, posto fora da lei e indiferente a esta, mas é abandonado por ela, ou seja, exposto e colocado em risco no limiar em que vida e direito, externo e interno, se confundem" (AGAMBEN, 2010, p. 35). "[...] o homo sacer apresentaria a figura originária da vida presa no bando (abandono) soberano e conservaria a memória da exclusão originária por meio da qual se constituiu a dimensão política" (AGAMBEN, 2010, p. 84).

8 Para exemplificar o fenômeno, Agamben menciona a military order outorgada pelo presidente Bush Jr., em 13 de novembro de 2001, após o ataque ao World Trade Center e ao Pentágono, que autorizou a detenção, por tempo indeterminado, de estrangeiros suspeitos de atos terroristas e o seu encaminhamento às "comissões militares", que não se confundem com os tribunais militares ordinários, por se tratar, justamente, de comissões especiais de julgamento. No mesmo sentido, o USA Patriot Act, promulgado na mesma data pelo Senado dos Estados Unidos, lei que permite "manter preso o estrangeiro suspeito de atividades que ponham em perigo a segurança nacional", estabelecendo o prazo de sete dias para que seja expulso sob acusação de violação da lei migratória ou de qualquer outro delito. Segundo Agamben, "a novidade da ordem do presidente Bush está em anular radicalmente todo o estatuto jurídico do indivíduo, produzindo, dessa forma, um ser juridicamente inominável e inclassificável" (AGAMBEN, 2007, p. 13). Sobre isso, consultar também: (JACOBSON; RUFFER, 2006, p. 38). 
Políticas migratórias no Brasil e a instituição dos "indesejados": a construção histórica de um estado de exceção para estrangeiros

9 [... " "...] o projeto democrático-capitalista de eliminar as classes pobres, hoje em dia, por meio do desenvolvimento, não somente reproduz no seu próprio interior o povo dos excluídos, mas transforma em vida todas as populações do Terceiro Mundo. Somente uma política que saberá fazer as contas com a cisão biopolítica fundamental do Ocidente poderá refrear esta oscilação e, por fim, a guerra civil que divide os povos e as cidades da terra." (AGAMBEN, 2010, p. 175).

10 Especilamente Die Diktatur (1921) e Teologia Politica (1922) (AGAMBEN, 2007, p. 17).

11 "A primeira foi em 1915 na França, com relação a cidadãos naturalizados 'de origem inimiga'; em 1922, o exemplo foi seguido pela Bélgica, que revogou a naturalização dos cidadãos que haviam cometido 'atos antinacionais' durante a guerra; em 1926, o regime fascista expediu uma lei análoga que dizia respeito aos cidadãos que se haviam mostrados 'indignos da cidadania italiana'; em 1933, foi a vez da Áustria, e assim por diante, até que a leis de Nuremberg sobre a 'cidadania do Reich' e sobre a 'proteção do sangue e da honra alemães', impeliram ao extremo esse processo, dividindo os cidadãos alemães em cidadãos a título pleno e cidadãos de segundo escalão, e introduzindo o princípio segundo o qual a cidadania era algo de que é preciso mostrar-se digno e que podia, portanto, ser sempre colocada em questionamento." (AGAMBEN, 2010, p. 129, grifo do autor).

12 As teorias genéticas, que se desenvolvem nas primeiras décadas do século XX, fundamentam o conceito de raça, que passa a ser político e influencia legislações relativas aos nacionais e não nacionais. Ao mesmo tempo, surge a preocupação institucional em se "fortificar a saúde do povo e eliminar influências que prejudicam o desenvolvimento biológico da nação." (AGAMBEN, 2010, p. 142-143).

13 Para uma análise aprofundada dessas características, recomendam-se as obras do antropólogo Darcy Ribeiro, especialmente, O Povo Brasileiro: a formação e o sentido do Brasil (RIBEIRO, 1995).

14 A justificativa para a exceção democrática funda-se no "estado de necessidade", identificado como uma situação de "perigo ou ameaça ao Estado", a impor medidas excepcionais dirigidas a uma região determinada do território ou a população específica (AGAMBEN, 2007, p. 44-49).

15 "O totalitarismo moderno pode ser definido como a instauração, por meio do estado de exceção, de uma guerra civil legal que permite a eliminação física não só dos adversários políticos, mas também de categorias inteiras de cidadãos que, por qualquer razão, pareçam não integráveis ao sistema político. [...] a criação voluntária de um estado de emergência permanente (ainda que não declarado no sentido técnico) tornou-se uma das práticas essenciais dos Estados contemporâneos, inclusive dos chamados democráticos. Diante do incessante avanço do que foi definido como uma 'guerra civil mundial', o estado de exceção tende cada vez mais a se apresentar como o paradigma de governo dominante na política contemporânea." (AGAMBEN, 2007, p. 13, grifo do autor).

16 Em 1903, os Estados Unidos também editam uma lei com os mesmos propósitos denominada Anarchist Exclusion Act.

17 A expulsão, associada à figura jurídica do impedimento de entrada e, como consequência, à responsabilidade da companhia transportadora em reenviar o imigrante ao seu país de origem, passa a ser o fundamento das leis migratórias aprovadas nas primeiras décadas do século XX e permanece como ponto fulcral das leis brasileiras a partir do Estado Novo. No Estatuto do Estrangeiro, recém-revogado, a palavra "expulsão" aparece 23 vezes em seu texto. A palavra "estrangeiro" é citada 134 vezes, ao passo que "imigrante", apenas uma. A Lei de Migração trata do instituto da expulsão na Seção 4 e a palavra aparece, com conteúdo restritivo, 20 vezes na nova lei.

18 "Distinguindo entre política (Politik) e polícia (Polizei), Von Justi conferia à primeira uma atribuição meramente negativa (a luta contra os inimigos externos e internos do Estado) e à segunda uma atribuição positiva (a tutela e o crescimento da vida dos cidadãos). Não se compreende a biopolítica nacional-socialista (e, com ela, boa parte da política moderna, mesmo fora do terceiro Reich) se não se entende que ela implica o desaparecimento da distinção entre os dois termos: a polícia torna-se então política, e a tutela da vida coincide com a luta contra o inimigo." (AGAMBEN, 2010, p. 143).

19 A expressão "Polícia Federal" é das mais recorrentes no Decreto 86.715/81 (BRASIL, 1981), que regulamenta o Estatuto do Estrangeiro (Lei 6.815/80) (BRASIL, 1980), ao ser mencionada 93 vezes. Na Lei 13.445/2017 (BRASIL, 2017), a palavra "polícia" aparece cinco vezes. Seu decreto regulamentar, que irá tratar das questões administrativas relativas ao controle migratório, ainda não foi elaborado.

20 A sesmaria é uma espécie de enfiteuse, em que o proprietário originário, governo português, cede o domínio útil de um imóvel a um terceiro para explorá-lo economicamente sob a forma de plantation. A sesmaria é uma grande extensão de terra, de dimensão imprecisa e a depender de cada contrato com o sesmeiro.

21 "[...] os imigrantes trazidos para os núcleos foram entendidos como potenciais agentes da europeização da cidade 
no processo de transformação que a elite cafeeira esperava da mudança do regime e da implantação do trabalho livre na Província. Esse imaginário republicano das elites paulistas desmascara-se com os conflitos, que, no decorrer da implantação dos núcleos, ocorreram entre o governo e os colonos. Revelou-se a distância entre os projetos concebidos e a realidade histórica, refletindo-se na mudança de função dos núcleos suburbanos de São Paulo após 1886, quando passam a servir como meio propagandístico para a atração de mão de obra no contexto da 'Grande imigração' das décadas de 80 e 90. [...] Os colonos viviam no núcleo em condição de isolamento, sendo constantemente vigiados e eventualmente punidos por seu comportamento. [...] o seu trabalho deveria ser vigiado, seu comportamento controlado e direcionado para as atividades 'produtivas', como a agricultura, para a produção de vinho, cereais e verduras o abastecimento da cidade. Desse modo, a proibição de cortar a lenha nas matas antes do pagamento dos lotes e, depois de emancipado o núcleo, proibição municipal de cortar qualquer lenha das matas em torno da povoação (Mata Atlântica), sem a permissão do município, formam circunscrevendo os limites de ação desses moradores. [...] o cuidado do governo não visava à preservação da mata virgem. Basicamente as medidas tinham três finalidades: fixar os colonos na terra, impedir que os imigrantes se emancipassem exercendo uma atividade lucrativa (venda de madeira) e impor a ideologia do trabalho." (ALVES, 2001, p. 56-60, grifo do autor).

22 Seyferth faz referência à identidade estereotipada atribuída aos italianos em São Paulo, chamados de "carcamanos" para satirizar "a ignorância e falta de polidez do imigrante", e, de modo similar, os poloneses rejeitavam a categoria "polaco", "de categoria estigmatizante, por denotar inferioridade". (SEYFERTH, 2011, p. 207).

$23 \mathrm{O} \mathrm{Art.} 3^{\circ}$ estabelece os princípios e garantias que regem a política migratória brasileira. O controle policial sobre a entrada e a permanência do imigrante é mantido na nova Lei de Migrações, conforme dispõem seus artigos 38 e 51.

24 Pacto Internacional sobre Direitos Civis e Políticos. Art. 12. Toda pessoa que se encontre legalmente no território de um Estado terá direito de nele circular e aí residir livremente. Toda pessoa terá direito de sair livremente de qualquer país, inclusive do dele. Os direitos anteriormente mencionados não poderão ser objeto de restrições, salvo quando estas estejam previstas na lei e sejam necessárias para proteger a segurança nacional, a ordem pública, a saúde ou a moral públicas, bem como os direitos e as liberdades de terceiros, que sejam compatíveis com os restantes direitos reconhecidos no presente Pacto (ORGANIZAÇÃO DAS NAÇÕES UNIDAS, 1966).

Convenção Americana sobre Direitos Humanos. Art. 22.1. Toda pessoa que se ache legalmente no território de um Estado tem direito de circular nele e de nele residir em conformidade com as disposições legais. 2. Toda pessoa tem o direito de sair livremente de qualquer país, inclusive do próprio. 3. O exercício dos direitos acima mencionados não pode ser restringido senão em virtude de lei, na medida indispensável, numa sociedade democrática, para prevenir infrações penais ou para proteger a segurança nacional, a segurança ou a ordem públicas, a moral ou a saúde públicas, ou os direitos e liberdades das demais pessoas. 4 . O exercício dos direitos reconhecidos no inciso 1 pode também ser restringido pela lei, em zonas determinadas, por motivo de interesse público (CONVENÇÃO..., 1969).

Convenção Europeia dos Direitos do Homem. Art. $2^{\circ}$. Da liberdade de circulação. Qualquer pessoa que se encontra em situação regular em território de um Estado tem direito a nele circular livremente e a escolher livremente a sua residência. 2. Toda pessoa é livre de deixar um país qualquer, incluindo o seu próprio. 3. O exercício destes direitos não pode ser objeto de outras restrições senão as que, previstas pela lei, constituem providências necessárias, numa sociedade democrática, para a segurança nacional, a segurança pública, a manutenção da ordem pública, a prevenção de infraç̧ões penais, a proteção da saúde ou da moral ou a salvaguarda dos direitos e liberdades de terceiros. 4. Os direitos reconhecidos no parágrafo 1 podem igualmente, em certas zonas determinadas, ser objeto de restrições que, previstas pela lei, se justifiquem pelo interesse público numa sociedade democrática (CONSELHO DA EUROPA, 1950, grifos nosso)

25 Foi o período de instalação do Núcleo de Nova Odessa, composto por famílias russas, do Núcleo Colonial "Campos Salles”, Núcleo Colonial "Dr. Jorge Tibiriçá”, Núcleo Nova Europa, Nova Pauliceia, Conselheiro Gavião Peixoto, Pariquera-Açu, São Bernardo, Conde do Pinhal, Nova Veneza, Visconde de Indaiatuba, Conde de Parnaíba, Cananeia, Martinho Prado Junior e Núcleo Colonial Bandeirantes. (BASSANEZI et al., 2008, p. 42-49)

26 São os termos do parágrafo 4º do artigo 69 da Constituição de 1891.

27 Um trecho da carta: "Patma Pizami, emigrante italiana, estabelecida na colônia de S. Bernardo, desta capital, que tendo chegado apenas há três meses da Itália, e não podendo, portanto, ainda obrigar os lotes de terra que lhe deram naquele núcleo a dar-lhe a alimentação necessária para sua subsistência e de seus filhos, não compreende o motivo por que o engenheiro diretor das colônias nega-se a dar-lhe alimentação. $\mathrm{O}$ mesmo engenheiro 
Políticas migratórias no Brasil e a instituição dos "indesejados": a construção histórica de um estado de exceção para estrangeiros

declarou que - se a suplicante não quisesse sujeitar-se a isso (tradução: se não quiser morrer de fome), retire-se da colônia. Oras, abusar assim da ignorância dos colonos é um ato inqualificável, além de ser uma falta de caridade. Iludir pobres estrangeiros, trazê-los para essa província, e pretender obrigá-los a atos impossíveis - é reduzi-los a uma escravidão pior que a dos nossos cativos. A suplicante, não sabendo assignar o seu nome, leva esse fato ao conhecimento de V. Ex. ${ }^{a}$ para dar as providências necessárias, certa de que, no Brasil, não é intuito trocar escravos brancos por escravos pretos. É uma obra de caridade, que muito distinguirá a administração de V. Ex. ${ }^{a}$ atender a suplicante." (ALVES, 2001, p. 70).

28 Decreto Estadual n. 2.653, de 5 de abril de 1916. (BASSANEZI et al., 2008, p. 62)

29 O governo foi autorizado pela Assembleia Legislativa a dar cumprimento ao tratado celebrado com a China, em 1890, e a celebrar tratado de comércio, paz e amizade com o Japão. No governo de Getúlio Vargas, a migração de orientais passa a ser veementemente combatida entre os deputados da Assembleia Constituinte de 1934 e, posteriormente, em 1936, por meio de Emenda Constitucional, sobre a qual nos deteremos no item subsequente, foram classificados como "indesejáveis".

30 O inteiro teor do decreto encontra-se em Brasil (1921).

31 "Art. $2^{\circ}$. Poderá ser expulso do território nacional, dentro de cinco anos, a contar de sua entrada no país, o estrangeiro a respeito de quem se provar: $1^{\circ}$, que foi expulso de outro país; $2^{\circ}$, que a polícia de outro país o tem como elemento pernicioso à ordem pública; $3^{\circ}$, que, dentro do prazo acima referido, provocou atos de violência para, por meio de factos criminosos, impor qualquer seita religiosa ou política; $4^{\circ}$, que, pela sua conduta, se considera nocivo à ordem pública ou à segurança nacional; $5^{\circ}$, que se evadiu de outro país por ter sido condenado por crime de homicídio, furto, roubo, bancarrota, falsidade, contrabando, estelionato, moeda falsa ou lenocínio; $6^{\circ}$, que foi condenado por juiz brasileiro, pelos mesmos crimes".

32 Estatuto do Estrangeiro. Lei 6.815/80. Art. $7^{\circ}$, III; Art. 65 (BRASIL, 1980).

33 Código Penal Brasileiro. Art. 338.

34 Lei 6.815/80. "Art. $2^{\circ} \mathrm{Na}$ aplicação desta Lei atender-se-á precipuamente à segurança nacional, à organização institucional, aos interesses políticos, socioeconômicos e culturais do Brasil, bem assim à defesa do trabalhador nacional." (BRASIL, 1980, online).

35 Decreto n. 19.482/1930. "Art. $7^{\circ}$ Os auxílios até agora dados nos núcleos coloniais aos imigrantes agricultores passarão a ser concedidos aos trabalhadores constituídos em família a que aludem os decretos n. 9.081, de 3 de novembro, e 9.214, de 15 de dezembro de 1911.” (BRASIL, 1930, online).

36 Decreto n. 24.258, de 16 de maio de 1934. "Art. 2 Os imigrantes agricultores ou jornaleiros rurais, constituídos, ou não, em famílias, só poderão entrar em território nacional se, além de não se acharem compreendidos em algum dos incisos do Art. $2^{\circ}$ do decreto n. 24.215, de maio de 1934, estiverem incluídos em qualquer das hipóteses, seguintes: [...] b) se constituídos em famílias, a existência de duas pessoas, no mínimo, maiores de 12 anos e menores de 60, aptas para o trabalho agrícola." (BRASIL, 1934a, online).

37 O Decreto n. 24.215/39 revoga o Decreto 4.247/1921.

38 Decreto n. 24.215/1934. Art. $2^{\circ}$, incisos VIII, X e XI (BRASIL, 1934b).

39 As condições de ingresso estão previstas nos três incisos do Art. $2^{\circ}$ do Decreto n. 24.258/24 (BRASIL, 1934a).

40 Agamben traduz essa exceção nos seguintes termos: "a lacuna não é interna à lei, mas diz respeito a sua relação com a realidade, à possibilidade mesma de sua aplicação. É como se o direito contivesse uma fratura essencial entre o estabelecimento da norma e sua aplicação e que, em caso extremo, só pudesse ser preenchida pelo estado de exceção, ou seja, criando-se uma área onde essa aplicação é suspensa, mas onde a lei, enquanto tal, permanece em vigor." (AGAMBEN, 2007, p. 49).

41 BRASIL. Decreto-Lei n. 406. 1938. "Art. $1^{\circ}$ Não será permitida a entrada de estrangeiros, de um ou outro sexo: I - aleijados ou mutilados, inválidos, cegos, surdos-mudos; II - indigentes, vagabundos, ciganos e congêneres; III - que apresentem afecção nervosa ou mental de qualquer natureza, verificada na forma do regulamento, alcoolistas ou toxicômanos; IV - doentes de moléstias infectocontagiosas graves, especialmente tuberculose, tracoma, infecção venérea, lepra e outras referidas nos regulamentos de saúde pública; $\mathrm{V}$ - que apresentem lesões orgânicas com insuficiência funcional; VI - menores de 18 anos e maiores de 60, que viajarem sós, salvo as exceções previstas no regulamento; VII - que não provem o exercício de profissão lícita ou a posse de bens suficientes para manter-se e às pessoas que os acompanhem na sua dependência; VIII - de conduta manifestamente nociva à ordem pública, à segurança nacional ou à estrutura das instituições; IX - já anteriormente expulsos do país, salvo se o ato de expulsão tiver sido revogado; $\mathrm{X}$ - condenados em outro país por crime de natureza que determine sua extradição, 
segundo a lei brasileira; XI - que se entreguem à prostituição ou a explorem, ou tenham costumes manifestamente imorais. Parágrafo único. A enumeração acima não exclui o reconhecimento de outras circunstâncias impeditivas, não se aplicando aos estrangeiros que vierem em caráter temporário o disposto nos incisos I, V e VI." (BRASIL, 1938a, online).

42 "Todas as escolas deveriam ter nomes brasileiros, só brasileiros natos poderiam ocupar cargos de direção, os professores deveriam ser brasileiros natos ou naturalizados graduados em escolas brasileiras, as aulas deveriam ser ministradas em português, sendo vetado o ensino de línguas estrangeiras para menores de 14 anos, as subvenções de governos e instituições estrangeiras foram proibidas. [...] Os militares pretendiam infundir a compreensão do jus soli como fundamento da nacionalidade em substituição à noção de jus sanguinis, desqualificada como exótica, estranha, evocadora de pátrias que não podem ser visualizadas." (SEYFERTH, 2011, p. 210).

43 "É determinante que, em sentido técnico, o sintagma 'força de lei' se refira, tanto na doutrina moderna quanto na antiga, não à lei, mas àqueles decretos - que têm justamente, como se diz, força de lei - que o poder executivo pode, em alguns casos, particularmente no estado de exceção, promulgar. O conceito 'força de lei', enquanto termo técnico do direito, define, pois, uma separação entre o vis obligandi ou a aplicabilidade da norma e sua essência formal, pela qual decretos, disposições e medidas, que não são formalmente leis, adquirem, entretanto, sua força." (AGAMBEN, 2007, p. 54-63).

44 A função normativa é atribuída ao Conselho Nacional de Imigração, presidido pelo Ministério do Trabalho (arts. 15 e 17 da Lei 6.815/80), os procedimentos administrativos de entrada e permanência, sempre afeitos a critérios de conveniência e oportunidade, são funções do Ministério de Relações Exteriores e do Ministério da Justiça (Art. 26). O Ministro da Justiça é competente pelas decisões em procedimentos administrativos de autorização de permanência e de expulsão do estrangeiro (arts. 65 a 70).

45 Nos termos do Art. 16 da Lei 6.815/80: "O visto permanente poderá ser concedido ao estrangeiro que pretenda se fixar definitivamente no Brasil. Parágrafo único. A imigração objetivará, primordialmente, propiciar mão de obra especializada aos vários setores da economia nacional, visando à Política Nacional de Desenvolvimento em todos os aspectos e, em especial, ao aumento da produtividade, à assimilação de tecnologia e à captação de recursos para setores específicos." (BRASIL, 1980, online).

46 Arts. 61, 69 e 139 da Lei 6.815/80 (BRASIL, 1980, online).

47 Lei de Migração. Art. $3^{\circ}$ A política migratória brasileira rege-se pelos seguintes princípios e diretrizes: [...] III não criminalização da migração (BRASIL, 2017).

48 Lei de Migração. Art. 49. A repatriação consiste em medida administrativa de devolução de pessoa em situação de impedimento ao país de procedência ou de nacionalidade (BRASIL, 2017).

49 O CONARE foi instituído pelo Estatuto do Refugiado, Lei 9.474/97, que regula sua estrutura e procedimentos (Art. 11 a 32).

\section{REFERENCIAS}

AGAMBEN, Giorgio. Homo Sacer: o poder soberano e a vida nua. 2. ed. Belo Horizonte: UFMG, 2010.

. Estado de exceção. 2. ed. São Paulo: Boitempo, 2007.

. Meios sem fim: notas sobre a política. Belo Horizonte: Autêntica, 1996.

ALVES, Alexandre. Os imigrantes do Núcleo Colonial de São Bernardo e a constituição do subúrbio paulistano. In: IOKOI, Zilda Márcia Grícoli. Diadema nasceu no Grande ABC: história retrospectiva da Cidade Vermelha. São Paulo: Humanitas/FFLCH/USP: 2001.

BASSANEZI, Maria et al. Repertório de legislação paulista e brasileira sobre imigração. São Paulo: Unesp, 2008. 
BRASIL. Decreto $n^{\circ}$ 19.482, de 12 de dezembro de 1930. Limita a entrada, no território nacional, de passageiros estrangeiros de terceira classe, dispõe sobre a localização e amparo de trabalhadores nacionais, e dá outras providências. Câmara, 1930. Disponível em: $<$ http://www2.camara.leg.br/legin/fed/decret/1930-1939/decreto-19482-12-dezembro-1930-503018-republicacao-82423-pe.html>. Acesso em: 17 jan. 2017.

. Decreto no 24.215, de 9 de maio de 1934. Dispõe sobre a entrada de estrangeiros em território nacional. Câmara, 1934b. Disponível em: < http://www2.camara.leg.br/legin/ fed/decret/1930-1939/decreto-24215-9-maio-1934-557900-publicacaooriginal-78647-pe. html >. Acesso em: 17 jan. 2017.

. Decreto $\mathrm{n}^{\mathrm{o}} 24.258$, de 16 de maio de 1934. Aprova o regulamento da entrada de estrangeiros em território nacional. Câmara, 1934a. Disponível em: <http://www2.camara. leg.br/legin/fed/decret/1930-1939/decreto-24258-16-maio-1934-557864-publicacaooriginal-78583-pe.html>. Acesso em: 15 fev. 2017.

. Decreto-Lei n. 406, de 4 maio de 1938. Dispõe sobre a entrada de estrangeiros no território nacional. Câmara, 1938a. Disponível em: <http://www2.camara.leg.br/legin/fed/ declei/1930-1939/decreto-lei-406-4-maio-1938-348724-publicacaooriginal-1-pe.html>. Acesso em: 17 jan. 2017.

. Decreto-lei no 479, de 8 de junho de 1938. Dispõe sobre a expulsão de estrangeiros. Câmara, 1938b. Disponível em: <http:/www2.camara.leg.br/legin/fed/declei/1930-1939/decreto-lei-479-8-junho-1938-349695-publicacaooriginal-1-pe.html>. Acesso em: 17 jan. 2017.

. Lei no 6.815, de 19 de agosto de 1980. Define a situação jurídica do estrangeiro no Brasil e cria o Conselho Nacional de Imigração. Presidência da República, Brasília, DF, 1980. Disponível em: <http://www.planalto.gov.br/ccivil_03/leis/L6815.htm>. Acesso em: 14 jan. 2017.

. Decreto ${ }^{\circ}$ 86.715, de 10 de dezembro de 1981. Regulamenta a Lei no 6.815 , de 19 de agosto de 1980, que define a situação jurídica do estrangeiro no Brasil, cria o Conselho Nacional de Imigração e dá outras providências. Presidência da República, Brasília, DF, 1981. Disponível em: <http://www.planalto.gov.br/ccivil_03/decreto/Antigos/D86715. htm >. Acesso em: 15 fev. 2017.

. Constituição da República Federativa do Brasil de 1988. Presidência da República, Brasília, DF, 1988. Disponível em: < http://www.planalto.gov.br/ccivil_03/constituicao/ constituicao.htm>. Acesso em: 11 out. 2017

. Projeto de Lei $\mathrm{n}^{\mathrm{O}} 5.655$, de 20 de julho de 2009. Dispõe sobre o ingresso, a permanência e a saída de estrangeiros no território nacional, o instituto da naturalização, as medidas compulsórias, transforma o Conselho Nacional de Imigração em Conselho Nacional de Migração, define infrações e dá outras providências. Câmara, 2009b. Disponível em: $<$ http://www.camara.gov.br/proposicoesWeb/fichadetramitacao?idProposicao $=443102>$. Acesso em: 11 out. 2017. 
. Decreto 6.975, de 7 de outubro de 2009. Promulga o Acordo sobre Residência para Nacionais dos Estados Partes do Mercado Comum do Sul - Mercosul, Bolívia e Chile, assinado por ocasião da XXIII Reunião do Conselho do Mercado Comum, realizada em Brasília nos dias 5 e 6 de dezembro de 2002. Presidência da República, Brasília, DF, 2009a. Disponível em: <http://www.planalto.gov.br/ccivil_03/_ato2007-2010/2009/decreto/d6975. htm>. Acesso em: 15 fev. 2017.

. Caderno de Propostas pós-Etapa Nacional: 1 Conferência Nacional sobre Migração e Refúgio. Brasília: Ministério do Estado da Justiça, 2014b. Disponível em: <http://www. participa.br/articles/public/0007/6551/COMIGRAR_Caderno_de_Proposta_PosEtapaNacional.pdf>. Acesso em: 13 ago. 2017.

. Câmara dos Deputados. Decreto no 4.247, de 6 de janeiro de 1921. Regula a entrada de estrangeiros no território nacional. Câmara, 1921. Disponível em: <http://www2. camara.leg.br/legin/fed/decret/1920-1929/decreto-4247-6-janeiro-1921-568826-publicacaooriginal-92146-pl.htm>. Acesso em: 9 ago. 2017.

. Anteprojeto de lei de migrações. 2014a. Disponível em: < http://ibrary.fes.de/pdf-files/bueros/brasilien/10947.pdf>. Acesso em: 16 jan. 2017.

. Redação Final do Substitutivo da Câmara dos Deputados ao Projeto de Lei $\mathbf{n}^{\circ}$ 2.516-b de 2015 do Senado Federal. 2016. Disponível em:<http://www.camara.gov.br/ proposicoesWeb/prop_mostrarintegra? codteor $=1516507 \&$ filename $=$ REDACAO + FIN AL+-+PL+2516/2015>. Acesso em: 15 jan. 2017.

. Lei no 13.445, de 24 de maio de 2017. Institui a Lei de Migração. Presidência da República, Brasília, DF, 2017. Disponível em: <http://www.planalto.gov.br/ccivil_03/_ ato2015-2018/2017/lei/L13445.htm>. Acesso em: 13 ago. 2017.

. Ministério Público Federal. Instauração do inquérito policial no 310/2016-4 SR/DPF/ MG: Habeas Corpus em favor de Maria do Rosário Barbato. Procuradoria da República no Estado de Minas Gerais, Minas Gerais, 2016. Disponível em: < http://www.mpf.mp.br/mg/sala-de-imprensa/docs/habeas-corpus professora-estrangeira-ufmg.pdf>. Acesso em: 13 ago. 2017.

CARNEIRO, Cynthia Soares. Imigração e igualdade: o diagnóstico dos imigrantes acerca da marginalização jurídica do estrangeiro no Brasil. In: CONGRESSO DO FÓRUM UNIVERSITÁRIO DO MERCOSUL - FoMerco, 15., 2015, Assunção do Paraguai. Anais... Assunção do Paraguai: FoMerco, 2015a. p. 416-424. Disponível em: < http://www.fomerco. com.br/conteudo/view?ID_CONTEUDO=294\&impressao >. Acesso em: 15 fev. 2017.

. Os Acordos de Residência do Mercosul frente ao Estatuto do Estrangeiro vigente no Brasil: obstáculos estabelecidos à sua efetividade sob a perspectiva do imigrante. Conpedi Law Review, Florianópolis, v. 1, n. 16. p. 64-95, 2015b. Disponível em: < http://portaltutor. com/index.php/conpedireview/article/view/217>. Acesso em: 15 fev. 2017.

CONEVA, Ada. A imigração açoriana para o Brasil meridional. 2009. Disponível em: 
$<$ http://www.premioiberoamericano.cz/documentos/15taedicion/3erPremioXV_AdaConeva. pdf $>$. Acesso em: 14 jan. 2017.

CONSELHO DA EUROPA. Convenção Europeia dos Direitos do Homem. 1950. Disponível em: <http://www.echr.coe.int/Documents/Convention_POR.pdf>. Acesso em: 14 jan. 2017. CONVENÇÃO Americana sobre Direitos Humanos. 1969. Disponível em: <http://www.pge. sp.gov.br/centrodeestudos/bibliotecavirtual/instrumentos/sanjose.htm > . Acesso em: 14 jan. 2017. DOMENECH, Geraldo. Inmigración, anarquismo y deportación: lacriminalización de losextranjeros "indeables" em tiempos de las grandes migraciones. Revista Interdisciplinar de Migrações Humanas, Brasília, v. 23, n. 45, p. 169-196, jul./dez. 2015.

GERALDO, Endrica. A Lei de Cotas de 1934: controle de estrangeiros no Brasil. Cadernos AEL, São Paulo, v. 15, n. 27, p. 175-209, 2009.

JACOBSON, David; RUFFER, Galya Benarieh. Social relations on a global scale: the implications for human rights and for democracy. In: GIUGNI, Marco; PASSY, Florence. Dialogues on migration policy. Oxford: Lexington Books, 2006.

ORGANIZAÇÃO DAS NAÇÕES UNIDAS. Pacto Internacional sobre Direitos Civis e Políticos. 1966. Disponível em: <http://www.planalto.gov.br/ccivil_03/decreto/1990-1994/ d0592.htm>. Acesso em: 14 jan. 2017.

RIBEIRO, Darcy. O povo brasileiro: a formação e o sentido do Brasil. 2. ed. São Paulo: Cia. das Letras, 1995.

SEYFERTH, Giralda. A dimensão cultural das migrações. Revista Brasileira de Ciências Sociais, São Paulo, v. 26, n. 77, p. 47-72, out. 2011.

UNITED NATIONS. International migration report 2015. New York: UN, 2016. Disponível em: <http://www.un.org/en/development/desa/population/migration/publications/ migrationreport/docs/MigrationReport2015_Highlights.pdf>. Acesso em: 13 ago. 2017.

VARGAS, G. Mensagem do Chefe do Governo Provisório. In: REPÚBLICA DOS ESTADOS UNIDOS DO BRASIL. Anais da Assembléia Nacional Constituinte. Rio de Janeiro: Imprensa Nacional, 1934. v. 1. p. 115-120.

WALLERSTEIN, Immanuel. The modern world-system. London: University of California Press, 2011. 4 v.

Submetido: 21 ago. 2017

Aprovado: 11 out. 2017 